\title{
AN EVALUATION OF THE SPITZ STUDENT RESPONSE SYSTEM IN PEACHTNG A COURSE IN LOGICAL AND MATHEMATICAL CONCEPTS
}

\author{
DISSERTATION \\ Presented to the Graduate Council of the \\ North Texas State University in Partial \\ Fulfillment of the Requirements
}

For the Degree of DOCTOR OF PHILOSOPHY

By

John David Erown, B.A., M.A. i)

Denton, Texas

May, 1971 
Frown, John David, An Evgluation of the Spitz Student Response Systen in Teachipg a Course in Logical and iratheratical Concepts. Doctor of Philosophy (College Teaching), May, 1971, 92 pp., 6 tables, 2 illustrations, bibliography, 61 titles.

The problem with which this investigation was concerned was that of determining the effect of teaching freshman mathomatics with the Spitz Student Response System upon a student's anxiety level, attitude and achievement.

The subjects were in the two sections of Mathematics 1308 which were taught by the investigator. Mathomatics 1308 is a general requjxement for all students not majoring in engineeing, science or mathematics. There were thirtynine students in the control section and thirty-iour students in the experimental section. The effects of the Spitz student Response System upon a student's anxiety level, attitude and cohievement were determined by use of statistical analysis upon pretest and posttest scores on the Mathematics Attjtude Questionnaire, IPAT Anxioty Scale Quostionaire and the Southern Methodist University Mathematios 1308 Placement Test.

The hypotheses and findings of this study are as follows

(I) Hypothesis I, that the adjusted mean achievement score of the students taught utith the aid of the Spitz Stadent Respona Systern would be significantly 
nigher than the adjusted mean achiovement score of the students taught by the regular lecture-recitation method, was not confirmed at the .05 levej.

(2) Hypothesis 2, that the adjusted mean anxiety score of the students taught with the aid of the spitz Student Response systern would be significantly lower than the adjusted mean anxiety score of the students taught by the regular lecture-recitation method, was not confirmed at the .05 level.

(3) Hyoothesis 3, that the adjusted mean positive attitude score of the students taught with the aid of the Spitz Student Response System would be significantly higher than the adjusted mean positive attitude score of the students taldght by the regular lecture-recitation method was not confirmed at the .05 level. However, the hyoothesis was confimed at the .10 level of significance.

(4) Hypothesis 4, that the adjusted meen achievement of the stikents with a positive attitude toward mathematics would be significantly higher than the adjusted mean achievement of the students with a negative attitude toward rathernatics was confirmed at the .025 lovel of significance.

(5) Hypothesis 5, that there would be significant interaction between the level of attitude and the method of instruction as variables affecting achievement in mathematics, was not confirmed at the .05 level. 
(6) Strbjectivo evaluation of the Spitz student Response System tended to suoport the system as a useful teaching device and one which imoroved the attitude of the students toward matheratics. The following conclusions were reached:

(1) It aoperiod that students learn as well using the Soitz Student Response System as by using more conventional methods.

(2) Based upon the subjective evaluation of the Soitz system by the students, one would have to conclude that the use of the system lessened anxiety in class by reinforcing the student's responses without calling attention to the individual student.

(3) Students taught by the lecture-recitation method augmented by the Soitz Student Response System definitely had a better attitude toward a required mathematics course than students taught the course by the regular lecture-recitation method.

(4) Students who had a positive attitude toward mathematics had a higher achievement level than those which had a nogative attitude toward mathematics. Because of the favorable subjective evaluation of the Spitz System, it is suggested that further research should be done using the Spitz student Response system before it is discounted as a teaching device. 


\title{
AN EVALUATION OF THE SPITZ STUDENT RESPONSE SYSTEM IN PEACHTNG A COURSE IN LOGICAL AND MATHEMATICAL CONCEPTS
}

\author{
DISSERTATION \\ Presented to the Graduate Council of the \\ North Texas State University in Partial \\ Fulfillment of the Requirements
}

For the Degree of DOCTOR OF PHILOSOPHY

By

John David Erown, B.A., M.A. i)

Denton, Texas

May, 1971 
TABLE OF CONTENTS

Page

ITST OF TABLES . . . . . . . . . . . . . . . V

LIST OF ILLUSTRATIONS . . . . . . . . . . . . . . vi

Chapter

I. INTRODUCTION ................ I

Statement of the Problem

Purposes of the Study

Hypotheses

Background and Significance

Definition of Terms

Basic As sumptions

Procedures for Collecting Data

Procedures for Analysis of Data

Suninary

II. SURVEY OF LHE LALERHURE . . . . . . . . I8

Studies Concerned with the Relationship of Anxiety to :chievement in Mathematics

Studies Concerned with the Relationship of Attitude to Achievement in Mathematics

Summary

III. DEVICES AND METHODOLOGY . . . . . . . . 34

Descripticn of Experimental Design and Samples

Instruments

Description of the Spitz Student Response Syistem

Procedures for Collection of the Data

Suminary

IV. FRESENTATION AND ANALYSIS OF DATA . . . . . 51

Treatment of the Data

Data Relative to the Hypotheses

Subjective Evaluation of the Spitz Student Response System

Summ ary 
V. SUMMARY, CONCIUSTONS, AND RECOMMENDATIONS . . . 67

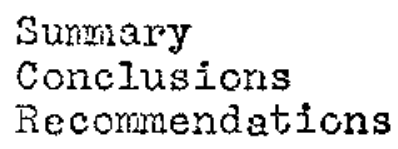




\section{LIST OF TABIES}

Table

Page

I. Analysis of Covariance Table Showing Sources of Variation for a Two-Hay Classification Between Levels of Attitude and Methods of Instruction Using the Pre-Achievement Scores and the Pre-Anxiety Scores as Covariates............... . . 54

II. Table of Adjusted Means and Standard Errors for Achievement Scores Using the PreAchievement Scores and the Pre-Anxiety Scores as Covariates . . . . . . . . 56

III. Analysis of Covariance Table for Anxiety Scores With the Pre-Anxiety Scores as the Covariate . . . . . . . . . . . 57

IV. Taule of Adjusted Means and Standard Errors for Anxiety Scores Using the Pre-Anxiety Scores as the Covariate . . . . . . . 58

V. Analysis of Covariance Pable for Attitude Scores With the Pre-Attitude Scores as the Covarjate . . . . . . . . . . 59

VI. Table of Adjusted Heans and Standard Errors for Attitude Scores Using the Pre-Attitude Scores as the Covariate . . . . . . . 


\section{LIST OF TLLUSTRATIONS}

Figure

Page

1. A Diagram of the Student Responder ..... 43

2. A Diagram of the Instructor Control

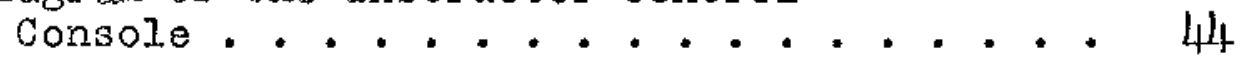




\section{OFAPTER I}

\section{INTRODUCTION}

The years which are soent as a college student are filled with many anxious and traumatic moments. It seems that the leve $\mathrm{i}$ of anxiety is significantly increased when an undergraduate student with very little background in mathematics finds himself required to take a freshman mathematics course.

Most of the research dealing with the relationships between anxiety, attitudes, and achievement in mathematics has been done on the elementary school level. Practically no research has been done with non-mathenatics majors who are required to take mathemitics courses in college.

It is possible that the anxiety felt by the undergraduate students in freshman mathematics is in part caused by their being required to take the course (which poses a real threat since they must pass the course) and by their attitude toward mathematics and mathenatically oriented subjects. Norton and. Poifenberger (I6) have found that the development of attitudes toward mathematics is a sumatory phenomenon with each conditioning experience building upon the one that precedes it. The initial attitudes seem to be develooed in the home and are effected not only by parents, but by all the teachers of mathematics with which the student is associated. Pupils who 
have done poorly or failed mathenatics have deflated egos and therefore tend to develop attitudes of dislike and hostility toward mathematics.

Part of the attitude developed about mathematics is probably caused by the way in thich this course has traditionally been taught. In the past few years, many new devices for teaching mathematics have been developed and some of them have shown to be helpful. One of the newest teaching devices is the Spitz Student Response System. The Spitz Student Response System is an electronic classroom communication system that individualizes group instruction by providing constant inteididion vetween the student and his instructor, as well as allowing the instructor to know exactly how well the entire class .. and each student $-\sim$ understands a particular presentation.

A Spitz Student Response System was installed at Southern Methodist University in a specially designed classroom in 1969 when Hyer Hall was refurbished. It was installed because of the successful results of some preliminary experiments conducted by Dr. W. J. Millard, of the Pan American Institute for Social Sciences and Educational Research, during tho 1967-68 school year. The author of this dissertation participated in those experiments and became very interested in the use of a student response system in group instruction. 


\section{Statement of the problem}

The problem of this study was the efiect of teaching Creshman mathematics with the Soitz Student Response System upon a student's anxiety level, attitude and achievement.

$$
\text { Purposes of the Study }
$$

The ourposes of this study were

(1) To compare the achievement levels of students enrolled in a required freshman mathematics course when taught by (a) regular lecture-recitation method, and (b) lecture-recitation method augmented by the Soitz Student Response System.

(2) To ascertain the effect of the spitz student Resoonse System uoon a student's anxiety level and his attitude toward mathematics.

(3) To analyze the effect of attitude on achievement in mathematics when the Spitz student Response System is used.

(4) To determine whether there was any interaction between student anxiety, attitude and method of instruction as variables affecting student achievenent.

\section{Hypotheses}

To carry out the purposes of this study, the following hypotheses were formulated: 
4

(1) The adjusted mean achievement score of the students taught with the aid of tho Spitz Student Resuonse system would be significanty higher than the adjusted mean achievernent score of the students taught by the regular lecture-recitation method.

(2) The adjusted mean anxiety score of the students taught with the aid of the Spitz Student Response System would be significantly lower than the adjusted mean anxiety score of the students taught by the regular lecture-recitation method.

(3) The adjusted mean positive attitude score of the students taught with the aid of the Spitz Student Response System would be significantly higher than the adjusted rean positive attitude score of the students taught by the regular lecture-recitation method.

(4) The adjusted mean achievement score of the students with a positive attitude toward mathematics would be significantly higher than the adjusted mean achievement score of the students with a negative attitude toward mathematics.

(5) There would be significant interaction between the level of attitude and the method of instruction as variables affecting the achievernent in rathematics, when the effects of anxlety were controlled statistically. 
Backgrovnd ừ Significance

\section{Backpround}

Many persons report in freshman mathematics classes that thoy are emotionaliy disturbed in the presence of mathematics or mathematically orjented material. It has been the experience of the writer that reactions of this nature to mathematical materials constitute a major field of emotionality in academic situations. And yet, as Dreger and Aiken (I) point out, although there have been many studies conducted to determine the effects of anxiety and attitude on arithmetic achievement, there has been essentially no controlled research in tho realm of emotional problems associated with higher level mathematics .. especially with regard to undergraduate non-mathematics majors in a mathematical situation (such as a required freshman mathenatics course).

Studies dealing with mathematics (on an elementary level) and anxiety generally fall into two methodological catogories. One set of studies has dealt with the somatic (body) expressions which are manifested by individuals when confronted with stimulus situations of a mathematical type. A more commonly used technique utilizes the papor-andwencil questionnaire. The subjects' responses to introspective questions are judged to be indications of anxiety level.

Hess (12) presented mental arithmetic problems of varying degree of difficulty to students and then obtained a trace of the size of the pupil of the eye. The size of the pupil tends 
to increase inmedately upur prosentation of the problem. The pupil reaches maximun size upon solution of the problem and then decreases in size. Milliken and Spelka (14) found that college freshmen with low mathomatics scores on the ACE examination tended to exhibit changes in breathing depth, blood pressure and heart rate when presented a mathematically related task.

Most of the siudies which used questionnaires have shown that there is a negative correlation between achievement in arithnetic and anxioty. Biggs $(5, p .59)$ concluded: .

In arithmetic and mathematics the inhibition produced by anxiecy appears to surnp any notivating effect, particularly where the children concerned are already anxions; or to put it mother rey, anxiety eppears to be more easily aroused in learnjug mathematics than it is in other subjects.

Dreger and Aiken ( 1 ) suggest that what is really involved is "anxieties" not "anxiety". They campied out a study on college freshmen and identified a syndrome of emotional reaction to mathenatics which they labeled "Number Anxiety". They found that a negative correlation existed between Number Anxiety and achievement in mathematics.

Morgan (15) found that thore is no significant correlation between test anxiety and achievement in mathematics on the high school level. Riggs (19, p. 3927) found that in college freshmen ". . anxiety and its adaptation apparently have an effect on learned responses such as adjustments and values, while they do not seemingly influence aptitudes and grade point averages. 
In the past rew years, anxiety and its effect on learning have played a role of primscy in investigations. In an exhaustive review of the studies of anxiety in children, Ruebush (20) pinpointed the current dilemna in which comparability of findings from different investigations was not oniy complicated by differences in theoretical definitions and orientation, but also by differences in operational criteria from study to study within the same theoretical framework.

Most studies dealing with anxiety in school situations assune that it has a debilitating effect on the learning process. Aaron and white (25), Woodworth (26), and Rethlingshafer (18) questioned why anxiety should be avoided or why anxiety should be scorned as an energizing determinant siraply because it is unmleasant. Dabrowski (7), postulating a theory of "positive disintegration," advanced the notion that anxiety could be healthy in certain ways. A.lpert and. Haber (3) reported two individual scales of facilitating and debilitating anxiety and used them to measure their effect on achievement.

In contrast to the somewhat confused picture in anxiety research, the research in attitudes provides a more stable situation. Fedon (10) found that some students have definite and relatively strong positive attitudes toward elenentary school mathematics, while others will have definte and relatively strong negative attitudes about the subject as early as the third grade. Faust (9), in studying more than 2,500 
elementary school students, found that of the "skill subjects", they preferred arithmetic first. Bassham (4) found a positive correlation between attitude and achievement.

Poffenberger and Norton (16), in a study of college freshmen, distinguished two subgroups, one positively oriented toward mathematics, the other negatively oriented. Both subgroups wore comparable in ability, support from parents, and general parental expectation. The analysis of the data dealt with sex differences, parental influence, and teacher influence on the development of attitudes toward mathematics. Sex did not seem to be a strong factor in the development of a positive attitude toward mathematics, but more than twice as many girls as boys have a strong negative attitude toward mathematics. Parents and parental expectation played an important role in the attitude formation exhibited by the student, but the other results were non-significant.

Other studies (Faust (9), Dutton (8), and Haskell (11)) seem to indicate that grade level, and sociometric grouping seem to affect attitude toward mathematics.

Poffenberger and Norton (16) found in their study that the development of attitudes toward mathernatics is a sumatory phenomenon with each conditioning experience building upon the one that preceded it. They also found that initial attitudes are developed in the home with the child's first contact with numerals as symbols. These findings have been verified by Ajken and Dreger (2) in their study along the seme lines. 
As far as the witer has been able to determine, there are not as yet any yublished studies which have utilized the Soitz Student Resoonse System. Wis is probably due to the nemess of the system.

\section{Significance of the Study}

Several aspects of the present study make it a potentially valuable contribution:

(I) The study added to the relatively small amount of research on the effectiveness of teaching college level mathematics.

(2) The present study added to the growing body of work on the effects of attitude on achievoment in college level mathematics.

(3) The statistical results of this study tended to cast doubt on the effectiveness of the Spitz Student Resoonse system as a teaching device in beginning college mathematics.

(4) The oresent study indicated that the use of the Spitz Student Response System tends to give students a more positive attitude toward mathematics.

(5) The subjective evaluation of the Spitz Student Response System terded to lend support to its use in beginning college mathematics. 
Dofinition of Forms

For the purposes of this stuay, the following definitions were formulated:

(1) Manifest Anxiety was the level of general stability, security, and mental health as reflacted by scores on the IFAT Anxiety Scale Questionnaire.

(2) Attitude was a learned predisposition or tendency on the part of an individual to respond positively or negatively to some object, situation, concept or another person.

(3) A Negative Attitude toward mathematics represented a score level less than 60 on the Mathematics Attitude Questionnaire.

(4) A Positive Attitude toward mathematics represented a score level greater than or equal to 60 on the Mathematics Attitude Questionnaire.

(5) Achievement in mathematics was measured by a score on the Bouthern Methodist University Mathematics 1308 Placement Examination.

\section{Limitations of the Study}

In keeping with University policy, this study was limited to the seventy-three students who were enrolled in the two sections of Mathematics 1308 (An Introduction to Logical and Mathematical Concepts) at Southem Methodist University, duping the f'a71 of 1970 . 
It is possible that the rosults of the study were in some way affected by the Farthorne Effect of the Soitz System.

\section{Basic Assumptions}

It was assuned that the subjects responded honestly to the instmaments used to measure manifest anxiety, attitude and achievement.

It was further assumed that the students, in the section in which the Spitz System was used, cooperated fully in its use.

Based on the preliminary research by Dr. Millard, it was assumed that the operation of the Spitz Response apparatus in no way jmoaired a student's note-taking or class participation.

\section{Procedures for Coliecting Data}

Subjects for this study were in the two sections of Mathematics 1308 which were assigned to the investigator at Southern Methodist University for the ill, 1970. Mathematics 1308 is a general requirement $\vec{i}$ or all students not majoring or minoring in engineering, science or mathematics. There were thirty-nine students in the conirol group and thirty-four students in the experimental group. One of the sections met in the specially designed classroom which houses the Soitz Student Response System (SSirs). This was designated as the experimental section. Whe freshmen at Southern Methodist 
University were registered for their courses through a personel conference with a University College Advisor. The actual scheduling of class sections was dore by a corps of schedulers who chose these sections for the student in a randorn manner. The student had no control over the section of a course in which he was placed.

The investigator taught the same material to each section, but in the experimental section, most class periods started with a series of questions which covld be answered on the SSRS. This allowea him to set $\theta$ baseline of understanding for the previous dey's lecture material. This naterial was then re-discussed or drilled if there was a need indicated. Throughout most of the lectures, the instructor used printed or mimeographed materials to present the instructional concepts and the related questions. In this way, the lesson was a continuous series of individual give and take, telling and asking, informing and inquiring, instructing and questioning. The investigator was able to pace himself by moving faster when the student responses were quick and sure. He stopped to amplify, clarify or redefine and explain when the responses indicated the majority of individuals did not understand.

With the SSPS, each student "conmuricated" with the instructor and could bo questioned by the instructor -privately. Wach studert had the reward of reaching his maximur level of echijovonent and vas required to maintain full 
involvement with the instmuctor. The SSRS allowed for instant reinforcement of the student for correct responses and an indication of wrong ones, all in a private manner. The first class meeting was devoted to informing the students in the experimental section about the SSRS. Both classes proceeded at approximately the same rate. The order of procedure for collecting data was as follows:

(1) The IPAP Anxiety Questionnaire under the title Seli Analysis Form was administered during the first and last weeks of class, to both classes.

(2) The Mathematics Attitude questionnaire was administered during the first and last weeks of class, to both classes.

(3) The Mathematics 1308 Placement Test was administered during the first and last weeks of class, to both classes.

(4) Using the definitions given earlier for positive and negative attitudes toward mathematics, the pretest scores on the Mathematics Attitude Questionnaire were divided into two grouos.

Procedures for Analysis of Data.

The tenability of all hypotheses of this study were tested in the null form at the .05 level of significance (two-tailed test). 
Hyootheses 1,4 and 5 were tested by using a $2 \times 2$ factorial analysis of covariance with the ore-anxiety score as the covariate. This allowed for simultaneous comparisons of the effects of multiple variables and determined whether a combination of these variables used for classification produced effects not attributable to any single variable.

Hypothesis 2 was tested by means of analysis of covariance with the oretest enxiety score being used as the covariate.

Hypothesis 3 was tested by means of analysis of covariance with the pretest attitude score being used as the covariate.

\section{Summary}

The intent of this chapter was to state the problem and to oresent the ourposes and significance of this investigation. Certain hyootheses were formulated and the methodological orocedures for their testing were outlined.

Chapter Two is a comprehensive review of the literature relevant to the problem of this investigation. 


\section{CHAPTER BIBIIOGRAPHY}

1. Aiken, L.R. and R.M. Dreger, "The Identification of Number Anxiety in College Populations," Joumal of Educational Research, LVII (December, 1957), 344-351.

2. "The Effects of Attjtude on Performance in Mathematics," Journal of Educational Psychology, LIT $(1961), 19-24$.

3. Alpert, Richard and R.N. Haber, "Anxiety in Academic Achievement Situations," Joumal of Abnormal and Social Psychology, LXI $(1960), 207-215$.

4. Bassham, Harre11, "Teacher Understanding and Pupil Efficiency in Mathematics - A Study of Relationships," The Arithmetic Teacher, IX (November, 1962), 383-387.

5. Biggs, John B., "The Psychopathology of Arithmetic," New Approaches to Teaching Mathematics, Eaitor F.W. Land, NeW York, St. Martin's Press, 1965.

6. Buros, Oscar K., Editor, The Sixth Mental Measurements Yearbools, Highland Park, New Jersey, The Gryphon Press, 1965.

7. Dabrowskj, K., Positive Disinterration, Boston, Little, Brown and $\mathrm{Co}, 1964$.

8. Dutton, Wm.H., "Attitudes of Junior High School Pupils Toward Arithmetic," School Review, IXIII (January, $-1.956), 18-22$.

9. Faust, Claire E., "A Study of the Relationship Between Attitude and Achievement in Selected Elementary School Subjects," Dissertatior Abstracts, XXIII (February, 1963), $2752-2753$.

10. Fedon, Peter, "The Role of Attitude in Iearning Arithmetic," The Arithmetic Teacher, V (Decomber, $1958), 304-320$.

11. HaskeII, Simon, "Some Observations on the Effects of Class Size Upon Pupil. Achievement in Goometrical. Draving," Joumal of Educational Research, IVIII (September, 1964 ), $27-30$. 
12. Hess, Eckhard H., "Attitude end Pupil Bize," Scientific American, CCXII (Aprit, 1965), 46-54.

13. Milliken, R.I., "Mathomatical.Vorbal Ability Differentials of Sitvetional Anxiety as Measured by Blood Pressure Change," Journal of Experimental Education, XXXII (september, 1964), 309-311.

14. and Bernard Spelka, MathematicaI-Verbal Ability Differentials and Somatic Expressions of Situational Anxiety, "Joumal of Experimental Education, XXXI (Septeriber, 1962), 3-26.

15. Morgan, Jas. H., "The Relationship Between Levels of Anxiety and Mathematics Achievernent in Programmed and Teacher-Directed Instruction," Dissertation Abstracts, XXV $(1965), 3760$.

16. Poffenberger, Thomas and Donald Norton, "Factors in the Formation of Attitudes Toward Matheratics," Journal of Educational Research, LII (January, 1959), 171-176.

17. _. "Factors Determining Attitudes Toward Arithmetic and Mathematics," The Arithmetic Ieacher, III (April, 1956), $113-116$.

18. Rethlingshafer, Dorthy, Motivation as Related to Personality, New York, McGrew-Hili, 1963.

19. Riggs, Cassidy Leroy, "The Relatjonship of Anxiety and Anxiety Adaptation to Aotitude, Selr-Concept, and Scholastic Achievement," Dissertation Abstracts, XXII (1961), 3927 .

20. Ruebush, Britton K., "Anxiety!" Child Psychology, SixtySecond Yearbook of the NationeI Society for the Study of Education, Part 1, Chicago, Univensity of Chicago Press, 1963.

21. Sarason, S.3., et al., Anxiety in Elementary School children, New York, John Wiley and Sons, Inc., 1960.

22. Schejer, I.H., and R.B. Cattell, Handbook for the IPAT Anxiety Scale Questionnaire, InInots, Institute for Personalay anô Ability Testing, 1967.

23. Taylor, Janet A., "A Personelity Scale of Marifest Arxicty" Joumet of Abnomed and Social Psychology, XIVIII $(1953) * 285-290$. 
24. Tulock, Mary K., "Lnotiona] Blocks in Mathematics," The Mathematics Teacher, I (Decembers 1957), 572-576.

25. White, W.F. and Robert I. Aaron, "reacher's Motivational Cues and Anxiety in Relation to Achievement Levels in Secondary School. Matherlatics," Journal of Educational Research, LXI (1967), 6-9.

26. Woodworth, R.S., Dynamics of Behavior, New York, Henry Holt and Company, 1958 . 
CHAPTER IT

SURVEX OF THE LITERATURE

In order to present a comprehensive survey of the liter. ature related to the problen of determining the effects of anxiety and attitude on achievement in mathematics, the investigator chose to organize the relevant research into two categories. These categories will be the research related to the effect of anxiety on achievement in matheratics and the research related to the effect of attitude on achieviment in mathematics. At the present time, there is no pubIished research about the Spitz Student Response System or its effectiveness. Therefore, this dissertation will be a pioneer work in that respect.

Studies Concerned With the Relationship of Anxiety to Achievement in Mathematics

The word anxiety occurred in the English languege for the first time about 1525 (20). It aid not become an object of scientific consideration until the use of twentieth century experimental psychology. More has been researched and written on the subject during the past two decades than ever before (27). One of the primary reasons for this was the development of the first videly used enxiety scale in the eariy 1950 : 
The Manifest Anxiety Scale was developed by Janet Taylor $(32,33,34)$. It consisted of items selected from the Minmesota Multiohasic Personality Inventory. The scale evolved from an attemot to measure Hull's D or drive in human subjects (27).

Extensive use of this scale olus different specific needs by other researchers quickly led to the develoument of other scales. Freeman (II) developed the Anxiety Scale in 1953. Bendiz (7) devised a short form of Taylor's scale in 1956. Welsh (37) developed the Uelsh Anxiety Index in the same year. Sarason (28), Alpert and Haber (5), and others have all develooed various varieties of anxiety scales. As data accumulated from studies utilizing these scales, it became apoarent that they were not all measuring the seme thing (27).

Anxiety is an important construct in theories of behavior, ranging from psychoana?ysis to learning theory, and most authors tend to use a theoreticelly derived definition, although some use emoirically derived definitions. The comparajilty of ijnaings from different studies is not only complicated by differences in theoretical definitions but also by differences in operational criteria from study to study within the same theoretical framework. $(26,0.461)$.

As a result, this resulting proliferation of anxiety studjes produced increasingly divergent data. Some of the more invortant studies are reviewed in the following paragraons.

It has been the experjence of most mathematics teachers in requirod mathematics courses to rote a great doal of 
dislike of matheraties on the part of their students. Dislike is certainly there, but there is something else besides. A student can enter an examination in English heartily disliking the subject, but he may stilj come out with respectable results, whereas if he really dislikes mathematics, it is a fairly safe bet that he will fail his examinations in it. This extra factor has been variously described as number anxiety" or "mathemaphobia".

Schonell (31) observed that backwardness in orithmetic is due as much to emotional as to intellectual factors, and psychoanalyitic writers $(13,14,23)$ suggest that failure in arithmetic may be related to maternal overprotection. Dreger and Aiken (9) identified a syndrome of emotional reactions to arithmetic and mathomatics which they designated as "number anxiety". The Dreger and Aiken (9) study was conducted with seven hundred and four students in basic mathematics classes at Florida State University. The investigators modifiec the Taylor Manifest Anxiety Scaje to includo several items specifically designed to measure feelings of anxiety concerning working with numbers. Their findings were as follow:

(1) Number Anxiety does appest to be a separate (composite)factor from "general. anxiety".

(2) Number Anxiety does not sem to be related to general intelligence as measured by the Wechsles-believie or ACE Scales. 
(3) Persons with high Number Axxiety do tend to make lower mathematics grades.

Biggs (8) points out that it is well known that anxiety can exert two fundamentally different effects on learning -on the one hand, st can be used to motivate the learner, and so improve his learning, but on the other, too much anxisty can inhibit and depress learning. Biggs further points out that other things being equal, we car expect the best performance in a given learning task to come from the Iearner who is relatively anxious. Obviously, both those who "could. not care less" how well they did, and those who were abso. Iutely terrified of making a mistalre, would perform badly in comparison. Naturally, there are wide inaividual difierences in reaction to enxiety some people can cope with a very high level of anxiety before going to pieces but, in general, it is clear that whether anxiety motivates or inhibits in a given situation depends upon the degree of enxiety jnvolved. Sarason, Mendlex, and Craighill (29) imply that measurable anxiety responses, when present, are debilitating on performance. Alpert and Haber (5) developed a scale that measured both facilitating and debilitating anxioty in academic achievement situations. It was determined in their study that prediction of academic achievenent was moh increased when both scales were used. Phillips (22) in hils study entivled "Sex, Social Olass, and Anxiety as Sowreos of Variation in School hohieverent", found that sox difperenoos 
existed in level of anxiety with males having lower anxiety scores than females; also, differences in the achievement of subjects with high and low onxiety were found, with high anxiety being associated with lower achievement. In general, he found that anxiety as a debilitating factor was more evident in relation to teacher grades than in relation to achievenent tests, with the achievement of lower-class nales being less affected than the achievement of other adojescents. These findings might best be interpreted in light of tho speculation by Sarason, Davidson, Ljghthall, md Waite (30) that the expression of anxiety j.s incongruous to the male's conception of himself, and this causes him to be more defensive in admitting anxioty and thus obtain a lower anxiety score than females.

Mckeachie (15) demonstrated. that the classroom atraosphere set by the teacher directly affected the anxiety level. of freshmen students and their test grades. Riggs (25) showed that anxiety and its adaptation apparentiy have an effect on learned responses such as adjustments and values, while they do not seemingly influence aptitudes and grade point averages to any significant degree.

Again, as Biggs (8) points out, it js clear that there are wide individual differences in reactions to enxiety but, in general, it is clear that whether anxiety motivatos or inhibits in a civen situation depends upon the degree of anxiety involved. Millor and Dollew (26) stated that 
comoletely self-satisfied people are poon learners. Anxiety belongs in the learning situation. In frct, anxiety (mild) can be looked upon as an essontial condition for leaming. Anxiety can have positive, healthy values and serve as a challenge to spark intelligent and creative behavior.

The significant thing is that this general relationship has been found to aoply to learning of all kinds... except, it seems, arithmetical and mathenatical leaning. Biggs (8) notes that in arithmetic and mathematies, the inhibition produced by anxiety appears to swamp any motivating effect, particularly where the children concerned are already anxious; to put it another way, anxiety aooears to be more easily aroused in learning mathematics than it is in other subjects. He feels that the reason for this is found in a combination of two factors: the manner of learning that the current teaching methods encourage, snd the nature of mathematics itself. Milliken and Soilka (17) showed that breathing rate increases, blood pressure elevates and heart rate increases when a student finds himself in a mathematical tyoe situation. Milliken (18) also found that to the extent that studertis exhibited mathematical dericit they did increase in anxiety under stressful mathematics testing for both sexes, as cor:trasted with only a sijght increase during verbal testing. Hess (12) found that the papil size of the eye increased upon the presentation of a mathentital probtem and it decreased

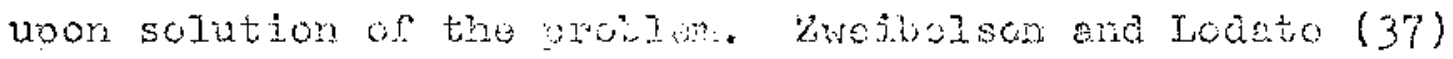


have pointed out that personal anxiety resulting from negative attitudes tovard arithretic produce a specific deterrent to arjthmetjc achievement. This deterrent appears specifjc enough to be called "arithmetic anxiety" or "number anxiety". It seorns $7 j k 0$ y that these negative attitudes toward rathematics and the subsequent avoidance or fear of mathematics may account for a lack of achievement in mathematical. type work. Zweibelson and Lodato (37) further point out thet this anxiety toward mathenatics may well develop prior to formal schooling. "One explanation of this may be found in the fact that exposure to the preciseness of arithmetic (mathematics) may cause anxiety which is generated by a fear of failure or of being wrong" $(37, \mathrm{p}, 140)$. Their study did find results to support the hypothesis that anxiety and arithmetic achievement were nogatively correlated.

The above results are somewhat dirinished by severaI studies such as the one by Morgan (19) in which no significant relationship between anxiety level and mathematics achievement was found. However, the majority of reserrch still agrees with the findings of Zweibelson and Lodato (37).

Studies Concerned with the Relationships of Attitude to Achievoment in Mathernatios

There have been several studies m.. Ajken (3), Dregex and Aiken (9), Dution (10), Pofienburger kria roxton (2h), ana Tulock (35) -. which suggest that portomence in mathematios 
is influenced by non-intellective as well as intellective variables. The simolest explanation for this fact is that pronounced fears in the presence of mathenatics and other negative fears toward mathematics result from exoeriences soecific to the leaming of mathoratics, in particular that the manner in which significant othors, viz., teachers and parents, instruct children in mathematics is the prinary determinant of their attitudes toward the subject (1). Norton and Poffenburger (2l4) have shown that the development of attitudes toward mathematics is a sumatory phenonenon with each conditioning experience building unon the one that precodes it. Initial attitudes are develooed in the hore with the child's first contact with numerals as symbols. When a child is confronted by numbers, he is affected not only by his teachers but also by the reactions of his perents to this newly introduced subject.

Aiken, (4, p. 589), in a very comolete and dotajled review of the research literature on attitudes toward mathematics, found that

Although it is certainly unfair to indjct teachers too strongly as creators of negative student atti.tudes toward nathematics, the results of research heve sug.. gested that the teacher, verhabs ever more ther the: parents, is an importart determiner of studeni attitudes. .. To orovido furthes intomation or the effects of teachen attitudes, more direct measures of teacher attitudes and their conseguences (e.g., by classroom observation) chould bo obtained. Student reports of peliecived teecher attitudes and teacher

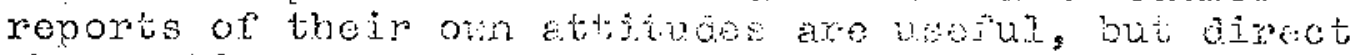

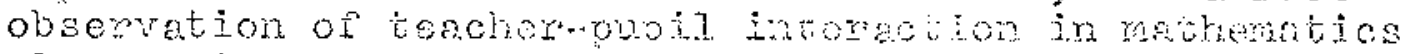
classes is also nooded. Tr addition, mole rutertion 
should be paid to the mathenatics training of elementary sckocl teachere. If the 2 or of primacy holds, the influence of eleneritary teachers on pupil attitudes should be even greater than that of secondery teachers.

In addition, Aiken (2) found that attitudes are determined by teaching methoas in mathenatics, although individual differences in general intelizgence and terperament may affect the development of such attitudes. Evidence in his work also led to the conclusion that females tend to have a more negative attitude toward mathematics.

Anttonen (6) made a longitudinal study to examine the stability of mathematics attitude over a six-year period. The pexiod he chose extended from the firth and sixth grade level to the eleventh and twelfth grade level. His study involved 1,017 students in St. Paul, Minnesota. He found that attitude toward mathematics changed over the six-year period and that the elementary and secondary attitude scores were positively correlated. Anttonen (6) also found that the secondary attitude score had a high positive correlation with the mathematics achievement scores on the secondary level. Aiken and Dreger (I, p. 1.9) have shown that

1. Math attitude scores made a significant con-tribution to the prediction of final grades in a mathematics course.

2. Math attitude scores prodict gairs in scores from irsitial to final edministration of a mathenatics achievement test whor tratuing has intorvered.

3. Moth attitudes aro positively correlated with numerical ability. 
4. Math attitudes ere positively comelated with subject's ratings of former mathematics teachors.

5. Math attitudes are positively correlated with subject's reports of early parental encouragement of mathernatics ondeavors.

Neidt and Hedtund (21.) Investigated the relationship betwoen change in a student's attitude toward a class in which he was participating and his final achievement in that class, with ability held constent. They postulated that certain poriods during a learning experience might be identified during which attitudes toward the learing experience were clearly related to final achievement. The expected modol of this relationship was one of increasing congruence between attitudes and final achievement as the class progressed. The results of their study show that student attitudes toward a particular learning experience do become progressively nore closely related to achievement in the leaming experience as the period of instruction progresses. It ves also found thet attitudes are significantiy related to finsl course grades rather early in the period of instruction.

Aiken (4) reviewed nost of the researeh on attitudes toward methematics since 1960 . Arong his critjejsms of research on atiitudes toward mathematics wete tre usc of crude measures of attitudes, excssive reituce on correlaw tional methodn, inuroper use of covaxtano gnelysis, inadequate control of extranecus refiablet end failure to use adequate morisunes of chenge. 
It is clear that serious thought must be given to experiments concerned with temporary and more permanent effects of preschool and early school exoeriences on attitude toward and performance in mathematics. In both the development and modification of attitudes, and in training and remedial work, a question is how to make mathematics more interosting. New methods may be initially motivating, but their effects will not last if the teachers are poorly trained, the parents are not sympatheti.c, and the students are not successful in mastering the subject. (4, p. 593).

\section{Sumnary}

It has been the purpose of this chapter to review the professional literature relative to two points. The first point concerned the effects of anxiety on achievement in mathematics. The findings are somewhat contradictory, but the majority of studies seem to indicate that anxiety and achievement are negatively correlated. The relationship is not a simple one, however, as other variables such as mathemaphobia, sex, attitudes and prior experience with mathematics were found to interact.

The second point concemed the efiects of attitude on achievement in mathematics. The findings are more consistent and conclusive for attitudes than for anxiety. The research seems to indicate that the rore positive a person's attituae, the better will be his ecrievernent level in mathematics. Ar attitude score is ax exceslent predictor of rathematical achieverient, In general, abtidus sre a surnatory proncmenor with each condtiontrg experieroe butiulng loon the one thet 
precedes it $(24)$. It has boon found that girls seem to have a more negative attitudo toward nathematics than boys. Chapter Three is a description of the expexinental design, tho instruments, and the Spitz Student Response system. Also, the procedure used in the treatment of the data will be discussed. 


\section{CHAPTER BIBSTOARAPHY}

1. Aiken, L.R., Jr., and R.M. Dreger, "The Effects of Attitudes on Performance in Mathematics "Journal of Educ ational Psychology, LII (1961), 19-24.

2. Ajken, I.R., Jr., "Matheraphobja and Mathemephilia: An Analysis of Personal and Social Factors Affecting Performance in Mathematics," Disseriation Abstracts, $1960, p .1992$.

3. , "Affective Factors in Mathematics Learning: Coments on a Paper by Neale cind a Plan for Research," Journa] for Research ju Maibenatics Educatjon, I (J.970), 251-255.

4. _-..., "Attitucas Toward Mathematics," Revjew of Educationel Research, XI (1970), 551.596.

5. Alpert, R., and R.M Heber, "Anxiety in Acaremic Achievement Situations," Joumel of Abnornal and Sociological Psychology, IXI (1960), $207-215$.

6. Anttonen, R.G., "A Longjtudinal. Study in Mathoraticis Attitude," Journal of Educational Researoh, IXIX (1969), $467-471$.

7. Bendiz, A.W., "The Development of a Short Forrl of the Manifest Anxiety Scale, Joumal of Consulting Psychologists, XX $(1956), 384$.

8. Biggs, John, "The Psychopathology of Arithnetic," New Approaches to Mathoratics Teaching, Fajtor F.t. Land, New York, St. Martin's press, 1965.

9. Dreger, R.M. and L.R. Airen, Jr., "rine Identification of Number Anxiety in a College Population, "Joumal of Eoucational Research, XIVIII (2957), 34h-35I.

10. Dutton, W.H., "Measuring Attitudes Towred Arithnetic," Elomentary Sckool Journal, $1954-\cdot 55$; $21-32$.

11. Freeman, M.J., "The Dovelopment of a Test for the Moasurement of Anxiety: A Study of its Reliability and

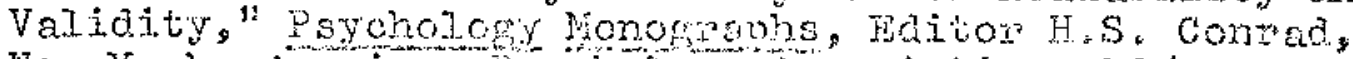

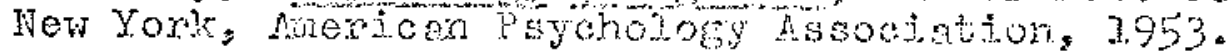


12. Hess, Eclhard H., "Attitude and Pupil Size," Scientiric American, COXII (1955), 46.5\%

13. Kloin, E., "Psychoanalytic Aspects of Scholastic Probleris," Psychoanalytic Study of the Child, Editors A. Frevd and Hartman, ITI-IV, NeW York, International Universities Press, 1949, 369-390.

14. Levy, D.M., MaternaI Ovemprotection, New York, Columbia University Press, 1947.

15. McKeachie, W.J., "Maturation, Teachjng Methods and College Learnings," Nebraska Symposiurn on Maturation, Editor M.R. Jones, Iincoln, University of Nebraska Press, 1961, 111-14.6.

16. Miller, N.E. and J. Dollard, Social Learning and Imitation, New Haven, Yale University Press, 1941.

17. Milliken, R.I., and Bernard Spilka, Mathematical Verbal Ability Differentials and Somatic Expressions of Situational. Anxiety," Journal of Experimental Education, XXXI (1962), 3-6.

-18. Milliken, R.I., Mathematical-Verbal Ability Differentials of Structional Anxiety as Measured by Blood Pressure Change," Journal of Experimental Education, XXXII (1964), 309-31j.

19. Morgan, J.H., "The Relationship Between Levels of Anxiety and Wathematics Achievement in Progremed and Teacher Directed Instmuction," Dissertation Abstracts, XXVI $(1965-66), 3760$.

20. Murray, Jas.A.H., et.al., The Oxford English Dictionarys London, University of oxford Press, 1933 .

21. Nejdt, C.O., and D.F. Hedlund, "The Relationship Between Changes in Attitude Toward a Course and Final Achievement," Journal of Edueational Reserirch, IXI $(2967), 56-58$.

22. Pintlips, B.M., "Sex, Social Ciass, and Anxiety as Sources of Variation in School Achjevement, "Joumel of Educational Psychology, I,III, 326-322.

23. Plank, I.N, and R. Plenk, "Fmotional Components in Arithmetical Jeaming os Seen Through Autobiograpkies," Psychosasiytic Study of the Child, Fdtors A. Freud and E. Wors, ix, Wev York, internationel universities Fress, 1952 . 


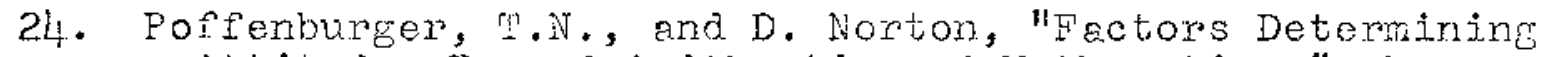
Attitudes Toward Arithmetic and Mathematics," The Arithmetic Teaches, III (1956), 113-116.

25. Riggs, L.R., "The Relationshjo of Anxiety and Anxiety Adantation to Aptitude, Self Concevt, and Scholastie Achievement," Dissertation Abstracts, 1961, 3923.

26. Ruebush, B.K., "Anxiety," Child Psychology, Sixty $\rightarrow$ Secora Yearbook of the National Socjety ior the Study of Education, Part I, Chicago, University of Chicago Press, 1963.

27. Sarason, Irwin G., "Wmpirical Findings and Theoretical Problems in the Use of Anxiety Scales," Psychologjeal Bulletin, IVII (1960), 403-475.

28. "Interrelationshios Among Inaividual Differing Variables, Behavior in Psychotheraoy, and Verbal Conditioning," Joumal of Abnomel and Socioloric el Psycholory, LVI (1958), 339-344.

29. Sarason, S.B., G. Mandler, and P.B. Craighi11, "The Erfect of Difiereiztial Irstuctions on Anxiety aird Leaming," Journal of Abnomin and Sociolorical Psychology, XLVII (1952), 561-565.

30. Sarason, S.B., K. Davidson, et.al., "Classroom Observation of High and Low Anxious Children," Child Develooment, XXTX (1958), 287-296.

31. Schonell, F.J., Dignosis of Inajviduel Differences in Arithmetic, Edinburgh, Oliver and Boyd, 1937 .

32. Taylor, Janet A., "The Relationshio of Anxiety to the Conditional Eyelid Response, Journal of Exoerimental Psychology, XII (1951), 81-92.

33. "A Personality Scale of Manifest Anxiety, Journal of Abromisl and Socjological Psychology, XIVIII $(1953), 285-290$.

34. - Psycholoey "Drive Theory and Manifest; Anxiety, " Psycholory jullotin, IJIT $(1956), 303-320$.

35. Tulok, M.K., "Frnotional Blocks in Mathematies," Mathematics Teacher, $V(1.95 \%) ; 572.576$

36. Welsh, Goo. S., "An Amxiety Index and on Mritemelization

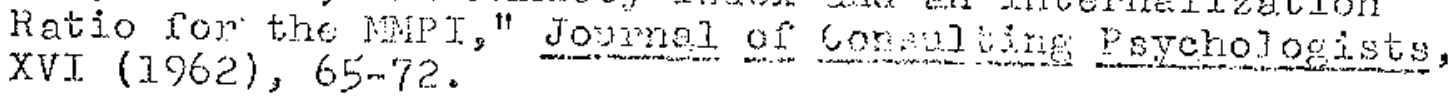


37. Zwejbelson, Irving and F. Trodato, "Relationship of Pupil Anxiety End Attitude to Arithmetic Readiness and Achievenent," PSychology ind the Schools, II (1965), $140-142$. 


\section{CHAPTER ITI}

\section{DEVICES AND NETHODOLOGX}

The purpose of this chapter is to describe the experim mental study which was conducted. The chapter is divided into sub-sections: the description of the subjects and the experimental design, the instruments used to evaluato the relativa effectiveness of the two teaching methods, student anxiety and attitude, the Spitz Student Fesponse System, and the procedures used in the collection of the data.

\section{Description of the Experinental}

Design and Sample

The subjects involved in this study were 73 freshren students at Southern Methodist University, Dallas, Texas. Subjects were enrolied in an Introduction to Logical and Mathematical Concepts, Math 1308, during the Fall Semester, 1970. An Introduction to Iogicaj and Mathematical Concepts is a required course for nom natrumatics and non-science majors and minors. The course was designed to include the basic concepts of elomontary matromatics and special emphasis was given to symojic logic and its application in mathonatics. Fotal exrollment in tho course was approximately 800 atudents. The expoximentel. group and control erop were the two soctions of wath 1308 whoh were tabght by the invostigntor. The 
students had no knowledge of who the teacher would be until the first day of class. Fhe control group met before the experimental group to keep any knowledge gained in the experinental group from being used on the control group inadvertently. Both classes were kept together in the presentation of the material.

The basic exporimental scheme of the study was a $2 \times 2$ factorial analysis of covariance design. There were two levels of attitude and two groups - a control group and an experinental group. This type of statistical design ellowed simulteneous comparisons of the effects of multiple variebles and determined whether a combination of these variables used for classification produced effects not attributable to any single variable.

According to Winer (9), factorial experiments pemit the experimenter to evaluate the combined effect of two or more experimental variables when used sinultaneously. Information is more corplate than single factor designs due to the evaluation of interaction effects. An interaction effect is an effect attributable to the combination of variables above and beyond that which can be predicted from the variables corsido ered sinfly, 1.e., in eddition to the information about the operation of exporimental. vaciabjes jn isolation, the experimenter can prodict whet will happen when two or more variables are used in combination. Anso, acoung to winer, if one uses a lactorial destin, tho resuits aro moro goneralizable 
than if a single factor expepinont is used because the estimates of the effects are obtained by averaging over a relatively broad range of other relevant experimental variables without having to hold them constant.

In addition to using a factorial design, the investigator chose to use analysis of covariance as a means of introducing an additional factor into the factorial expeximent. As Lindquist (4, p. 334) points out,

most people enoloy analysis of covariance to increase the precision of the experiment and to adjust for initial differences between the groups and not because the relationship of the control and criterion measures was of any interest in itself. In many instances, however, the $\mathrm{X}$-factor mey be introduced for exactly the same reasons that any other "f getor" is introduced in a factorial experiment - that is, in order to study its relationship to the other factors or the manner in which it may affect the comparisons within any of the other classifications.

In the case of the present study, the anxiety score was introduced as a covariate so that by the method of analysjs of covariance the mean scores on the criterion achievement tests could then be adjusted so as to study the offect of anxiety on achievement for the comparison of the subclasses.

\section{Instruments}

After reviewing the availability of standardized tests (2) in matromatics, it was decided that there were no appropriate standardized achieverent tests to measure the outcome of the course, An Introduction to logicen and Mathemetical Conepta. Whe comes otweses the understanding 
of logjcal and mathematical conopts retrer than skill in performing basic operations. Most of the available standardized tests evaluate basic skills. Fhose standardjed tests which do evaluate concepts do not include all the concepts taught, in the course, An Introduction to Logical and Mathomatical Concepts, Mathenatics 1308. The instrument chosen was the Placenent Test used at Southern Methodist University. This test is given at the beginning of each semester to those students who wish to take it. If a student scores 70 or higher ou this Placernent Test, he is Eranted credit for Mathematics 1308 . The instrument is consjdered to have content validity in the judgment of the investigator for the following reasons:

(1) The investigator was a member of the committee which designed the course ond feels competent to judge the test.

(2) The investigator was co-author of the text for the course.

(3) The investigntor has taught the course over twenty times to over 100 etudents using essentially the same questions on the jinstrunent as a basis for evaluating student aghiovenent the the course.

(4) The instrument is the result of pooling items suggested by all rectly jorolved in traching the course. The faculty is in fuld egroment thet the instrument measures the oonecpts ata atne of the course. 
(5) The instrument is highly refined through constant revision, discarding inaporopriate items and adding new items through common agreement by the faculty involved in teaching the course.

(6) It is assumed that the content of the present course did not differ significantly from that of previous courses and that the investigator conducted the course using his usual approach.

The test was found to be internally consistent because a split-halves reliabjity coefficient of .81 was determined for this test.

Noms have been establishod for the examination with a - mean of 71.69 and a standard deviation of 13.35. A copy of the Placement Test appears in Appendix A.

The present study made use of the Mathematics Attitude Scale which was develooed by Dr. Lewis R. Aiken, Jr., (Women's College of the University of North Carolina), and Dr. Raloh M. Dreger (Jacksonville Uriversity) for use in several papers which they wrote. It is an opinionnaire which makes use of a five-point scale from strongly disagree to strongly agree on each item. The Mathematics Attitude Scale is actually two scales in one. There is a ten item scale to measure positive attitude and a ten item scale to measure negetive attitude. The test was scored to yield a positive attitude score winch is the sum of the values on all. twenty iteme. An arbitrary cutorl point of 60 was used to divide 
the scores into two levels. Ihe scores of 60 and above were said to represent a positive attitude toward mathenatics while those scores less than 60 were said to represent a negative attitude toward mathematics.

According to Aiken and Dreger (1) this psychometric instrumert of twenty items was constructed by the likert attitude scaling techniaue. The test retest relibbility was found to be $r=.94$. In addition, a test of independence between the scores on the attjtude scale and scores on four items designed to measure attitudes toward academic subjects in general suggested that attitudes specieic to mathemetics were boing measured $\left(x^{2}=.80\right.$, df $\left.=1\right)$.

According to Aiken and Dreger (1), the instrument has face or content validity. Also, a partial correlation was detemined betreen scores on the Mathematics Attitude scale and retest scores on the Mathematics Pretest fos College Students, partialling out the eifects of initial scores on the latter test. They treated the data separately for one hundred males and one hundred females and found concurrert validity for the instrument in the form of signilicant partial correlation coefficjents of .33 and .34 for mazes and remales resoectively.

Aiken and Dreger (J) also esteblished predictive velidity coefficients of .67 and .63 fox males and fenales respectively. The oredictive coefficient for riales turred out to be sjightly jusighificant (at . ol, level of significence), but 
the Mathematics Attitude Sca?e was found to be a good predictor of achievenent for femeles. A copy of the Matheratics Attitude Scale appoars in Appendix B.

The present study also used the IPAT Anxiety guestionnaire which was designed and constructed by Br. R. B. Cattedt of the Institute ror Personality and $A b i l i t y$ resting. The Cattell Anxiety Seale consists of forty items and is presented in a test booklet labeled. The Self: Analysis Form (for it is considered undesirable for subjects to realize that it intends to measure anxiety). The main three scores are overt anxiety (syniptomatjo anxiety), covort (not conn sciously displayod, and total anxiety. The total burety scores are to be used in the present study. The mentat specifically distinguishes between arxiety and reuroticiem, and described the anxiety factor as being "a feature of neurosis (especially anxiety neurosis, but it is far from being the only feature of neurosis" (7).

The manual reported split-half reliebility of .84 on 240 nomal adults and.91 on 120 subjects in a nixed population of normals and hospitalized nourotics. Construct velidity wes estimated at .85 to .90 for the total scale. Feneles were reported to consistentiy average slightly highex ou a free anxiety level as compared to males. However, Cattell suggested that in correlational stadios and in some types of: research, no corrections for ser aro recesseny. The norm tables for the separate soxes rore suggostod ror use in 
counseling, where one mitht wish to know how a person stood in relation to a defined population. The manual al so sug.gests corrections for ages over 60 years. This will not be necessary, as no subjects in this study are that old. Thus, no corrections vill be made to the raw scores.

This instrument was chosen for several reasons. First, it was developed as the result of extensive research using Cattell's factor analysis technique. The forty iterns included in the final scele were selected from over four thousand original items. Second, the Cattell Anxiety Scale was developed for the stated puroose of diagnosis of anxiety. Third, it has received excellent reviews in Buros (2) by Jacob Cohen, J. P. Guilford and $\mathrm{E}$. Lowell Kolly. A copy of the Cattell (IPAT) Anxiety Scale appears in Appendix 0 .

\section{Description of the spitz student}

\section{Response System}

One of the nevest teaching devices is the spitz student Response System. The Spitz Student Response System is an electronic classroon cormunication system, that indivjdua].izes group instruction by providing constant interaction between the student and his inetructor, as well as allowing the instuctor to know oxacily how well tile entire class and each stucient . undonstands a perticular precentation.

A Spitz Student response System was instal]ed at Souther Hethodist iniversity in 1969 in en amphtheatre-type 
classroom in a refurbished building. The Spitz system was developed by the Spitz Laboretories, Ine., Chadds Ford, Pennsylvania, which is a division of the rickraw-Hill Book Compsiny.

The Spitz instalation g.t Southern Methodist University was instailed at a cost of approximately $\$ 38,000$. The System has sixty-eight individual student stations with a central. console ard a teleprinter installed at the center of the front of the room.

A diagram of the individual student responder is shomn in Figure $I_{\text {s }}$ and a diagrem of the central console unit is shown in Figure 2.

The Soitz Student Response System establishes studentteacher irteraction. It provides the instructor with a means of receiving instant responses from the class as a whole and from each individual in the class.

The response system is a general purpose question-andanswer tool. The foljowing are the basic values of the system as Ijsted in the Spitz Iiterature (8).

1. The Spitz Student Response System provides continuols student feedback to the instructor and gives him a permanent recoind of the responses.

2. The Spjtz Student Response System involves ald the students in the class and requires active, fulltime participation. The instructor lmows at what point student interest or comprehension falls dom, and he can inmediately stop or restate, roderine, clarify or drizl.

3. Trie studert has tho plossure and newerd of

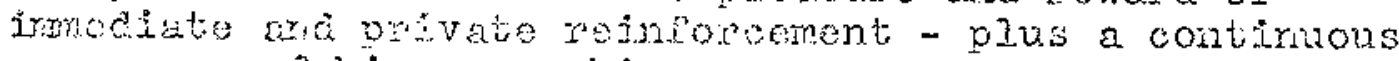
awenese of hiss ow achievenento 
FIGURE I

\section{STUDENT RESPONDER}

ready light-tells student when to answer
recessed answer choice and reinforcement light-

-five button choice-compatible with standard norms testing

illuminated alphabet wheel-to provide a permanent record of each student's name... and to provide for alphabetic responses

$\iint_{1}$

(

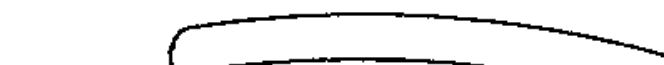




\section{NSTRUCTOR}

SCALE adjusts percentage Iight bars to class size

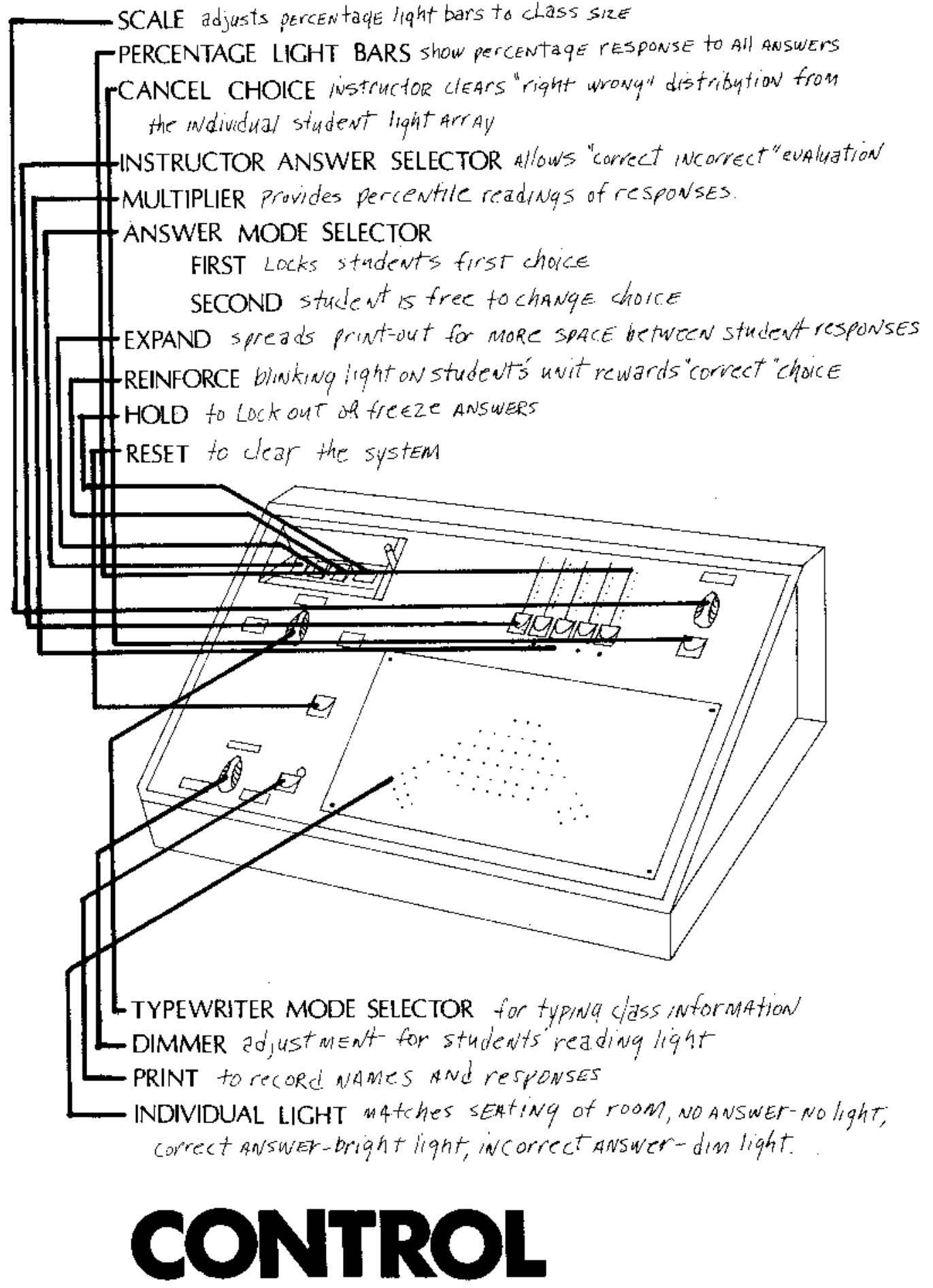


4. From a practical point of viev, the system provides for individualized instruetion vithin the large group teaching situation. It strengthens communcation between teacher and student.

In this study, the system was used as follows: At the beginning of each class period, each student vas presented a list of three or more questions dealing with the major points in the preceding day's lecture and class work. With the aid of the Spitz system, the investigator was able to detemine the level of group understanding for the concepts tested. The scaling device on the coirsole gave an indication of the percentage of correct responses to each question. It was arbitrarily decided thai any topje represented by a question

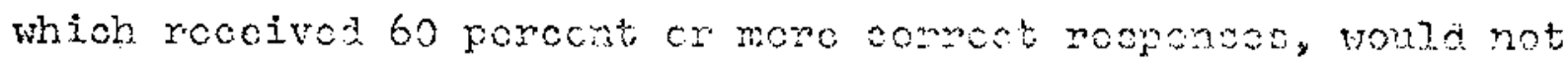
be discussed any furthex uniess some student mede a sperial. request for its discussion. Any toptc represented by a ques. tion which received less than 60 percent comect responses wes anplified and clarified through the review of the topic and the prosentation of adjitiond examples. This procedure allowed the investigator to get a base line for the learing level of the class on the preceding dey's matromial.

Since the irdiriduel responders furnished instunt rein forement for coxpact answers, the student; was aware of his correct responses as nell ss the incorrect onos. Because the student vas furnished a list of the onestions, he had the list with the correct respores tndigato, as veli as his

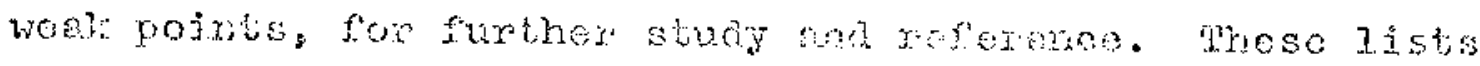


proved inveluables becavse when a student came in for a private conference, the investigator could refer to his specific problem areas and dilit. hin on them.

During the course of some of the lectures, other question and answer sessions were conducted and this allowed the lesson to be a continuous serjes of individual give and take. This procedure also allowed the investigator to pace himself and move more quick]y when the student responses were quick and sure.

Student participation was called for frequently, and each student had to maintain involvemont. This process of almost daily questioning over the preceding day's material forced the students to study the material dally and not procrastinate. The level of class comprehension seemed, in the opinjon of the investigator, to be better and faster than the control group. The noed for daily stuay might have been the factor involved in this phenomenon. The daily question lists had the added advantage of giving the student a preview of typical exanination quostions as well as pinpointing areas of particular importiance.

Because of the use of the mineographed lists of questions, there was no need for the automatic printout data. Whe Teleprinter is an extromely noisy instrumont and this noise js a groat astrection. The invositgator foels that this is a docided roalnoss in the systom. 
Procedures for Col Jecting Data

Subjects for this stuay were in the two sections of Mathematics 1308 which were assigned to the investigator at Southem Methodist University for the fall of 1970. Mathematics 1308 is a general requirement for all students not majoring or minoring in engireering, science or matrematics. Thexe were thirty-nine students in the control group and thirty-four students in the experimental group. The experimental section met in the specialy designed classroom which houses the Soitz Student Fesponse Syster. The freshmen at Southern Methodist University were ajl registered for their courses through a personal conference with a University College Advisor. The actual scheduling of class sections was done by a coros of scheduleis who chose these sections for the student in a random manner. The student had no control over the section of a course in which he was placed.

The investigator taught the same materjal to each section, but in the experimental section, each class period started with a series of questions which could be answered on the Spitz Student Resoonse System. This allowed him to set a base line of understendirg for the previous dey's lecture material. This material wes reaiscussed or arilled if there was a neod indicated. Througloot the lecture, the instructor used orjoted or rimeograthed mnterials to present the instructional concopts and the relatod questions. In this way, the Jeston was t continuous sertes of incividual infomation and 
inquiry. The investigetor was able to pace hjmself by moving faster when the student responses were quick and sure. He stopped to amplify, clarify or define and explain when the responges indicated the majority of individusls did not understand.

With the Spitz Student Response System, each student "communicated" with the instructor and could be questioned by the instructor privately. Each student had the revard of reaching his maximum level of achiovement and was required to maintain full involverent with the instructor. The Spitz Student Response Systom allowed for instant reinforcement of the student for correct responses and an indicstion of wrong ones, all in a private manner.

The first class meeting was devoted to informing the students in the experimental section about the spitz student Response System. Both classes proceeded at approximately the same rate.

The order of procedure for collecting ata was as follows:

(1) The IPAT Anxiety Questionnaipe under the titie Self Analysis Form was administored curing the pirst and last wecis of class, to both classes.

(2) The Mathariatics Attitude Questionraire was admintsiered during the first and last weeks of class, to bouk c.lesses. 
(3) The Mathoratics 2308 Flacement Test wos administered durjing the first end last weeks of class, to both cIasses.

\section{Summary}

In order to secure the ata utilized in this study, anxiety, attitude end achievement instruments were solected and administered to a control section and an experimenta]. section of An Introduction to Logical and Mathematical.

Concepts, Mathematics 1308. The control group consisted of thirty-nine students and the experinental group had thirtyfour students. The independent variabies for the study were the anxiety score, attitude scoro, and group membership. The criterion measure was the achievement test given during the last week of class. The .05 level of significance was used to test all hypotheses.

In Chapter Elour the data and the results of the statis.. tical treatment of the data will be discussed in detail. 
1. Aiken, L.R., and R.M. Dreger, "The Identification of Number Anxiety in a College Population," Journal of Educational Research, LVII (2957), 344-351.

2. Buros, Oscar K., Editor, The Sixth Mental Measurements Yearbook, Highland Park, IJlinois, The Gryphon Press, 1965 .

3. Campbe11, D.T., and J.C. Stanley, Experimentel and Quasi-Exporimenta? Designs for Kesearch, ChIcago, Rand MeNaliy \& Co., 1966.

4. Lindquist, E.F., Design and Anolysis of Experimerts in Psychology and Education, Boston, Houghton-Mifilin \& Co.: 1956 .

5. Roscoe, J.T., Fundamental Research Statistics, Del.las, Holt, Rinehart and Winston, 3969 .

6. Sax, G., Emoirical Foundations of Educational Rescarch, New Jersey, Prentice-HaI1, I968.

7. Scheier, I.H. and R.B. Cattell, Handbook for the IPAT Anxiety Scale Questionnaire, Jilinois, Institute for personality and $A B i j$ t. Ty testing, 1967.

8. "Spitz Student System for Large Group Instmotion" An Advertisement by Spitz Laboratories, Inc., Chedds Ford, Pennsylvania, A Division of McGrawmiliz, Tne.

9. Winer, B.J., Statistical principles in Exporimental Design, New York, McGraw-Hill, 1962 . 
CHAPTE:R IV

PRESENTATION AND ANAIYSIS OF DATA

The basic purooses of this study were

(1) To compare the achievement levels of students enrolled in a required freshman mathematics course wher taught by (a) regular lecture-recitation method, and, (b) lecture-recitation method augmented by the spitz. Student Response System.

(2) To ascertain the effect of the spitz student Resonnse System unon a student's anxisty Jevel and his attitude toward matrematics.

(3) To analyze the effect of attitude on achievement in mathematics when the Spitz system was usod.

(4) To determine whether there was any interaction between student anxiety, attitude and method of instruan tion as variables affecting student achievement. To carry out the purooses of this study, the following hypotheses were formulated

(I) The adjusted mean achievenent of the students taught with the aid of the Soitz Student Response system would be significantly highei than the adjusted mean achievenent of the students taugh by the regular lecture-reotation methos. 
(2) The edjusted mean anxiety score of the students taught with the ajd of the soitz student Response System would be significantly lower than the adjusted mean anxiety score of the students taught by the regular lecture-recitation method.

(3) The adjusted mean positive attitude score of the students taught with the aid of the Spitz student Resoonse System would be significantly higher than the adjusted mean positive attitude score of the students taught by the reguler lecture-recitation method.

$\left(i_{4}\right)$ The adjusted mean achievement of the students with a oositive attitude toward mathematics would be significantly higher than the adjusted mean achievement of the students with a negative attitude toward mathematics.

(5) There would be significant interaction between the level of attitude and the method of instruction as variabies affecting achievernent in mathernatics when the efrects of anxiety were controlied statistically. The puroose of this chapter is to present the statistical data relative to these hypotheses.

\section{Treatmert of the Data}

The tenability of all the hypotheses op tilis stucy was tested ir the ruld form at the .05 level af signifirares. (two-tailed tost) 
Both the control grou and the exoerinental group were given, in a pre-test and post-test situation, the Cattell (IPAT) Anxiety Scale, the Mathematjcs Attitude Questionnaire, and the Mathematics 1308 Placement pest. The following definitions were used to determine the levels for the classification variables as required by the $2 \times 2$ factorial design.

(1) Manifest Anxiety was the level of general stability, security and mental health as reflected by scores on the IPAT Anxiety Scale Questionnaire.

(2) Attitude was a learned oredisoosition or tendency on the part of an individual. to respond positively or negatively to some object, situation, concept or another person.

(3) A Negative Attitude toward mathematics represented a score level less than 60 on the Matheratjos Attitude Questionaire.

(4) A Positive Attitude toward mathematics reoresented a score level greater than or equal to 60 on the Mathematics Bttitude Questionraire.

(5) Achievenent in mathenatics was measured by a score on the Southem Methodist Uriversity Mathemetics 1308 placernent Exemination. 
Deta Relative to the Hypotheses

Table I indicates the results of the analysis of covar.. iance for a two-way design between levels of attitude and methods of instruction using the pre-achievenent scoros and the ore-anyiety scores as the covariates.

\section{TABTIE I}

ANALYSIS OF COVARIANCE PABIE SHOVING SOURCES OF VARIATION FOR A TWO-WAY CLASSIFICATION BETWESN LEVELS OF' ATTITUDT AND METHODS OF INSTRUC'I'ION USING

THE PRE-ACHIEVEMENT SCORES AND THE

PRE-ANXIETY SCORES AS COVARIATES

\begin{tabular}{|c|c|c|c|c|c|}
\hline $\begin{array}{l}\text { Sources of } \\
\text { Variation }\end{array}$ & $\begin{array}{l}\text { Degrees } \\
\text { of } \\
\text { Freedom }\end{array}$ & $\begin{array}{l}\text { Adjusted } \\
\text { Sum of } \\
\text { Squares }\end{array}$ & $\begin{array}{l}\text { Adjusted } \\
\text { Mean } \\
\text { Squares }\end{array}$ & $\begin{array}{c}F \\
\text { Ratios }\end{array}$ & $\mathrm{p}$ \\
\hline $\begin{array}{l}\text { (1) Between } \\
\text { levels of } \\
\text { Attitude }\end{array}$ & 1. & 54.87 .42 & 5487.42 & 9.78 & .025 \\
\hline $\begin{array}{l}\text { (2) Betweer } \\
\text { methods of } \\
\text { instruction }\end{array}$ & 1 & 37.94 & 37.94 & .07 & N.S. \\
\hline $\begin{array}{l}\text { Interaction } \\
\text { between (i.) } \\
\text { and (2) }\end{array}$ & 1 & 127.50 & 127.50 & .23 & N.S. \\
\hline $\begin{array}{l}\text { Wthin } \\
\text { Feojicates }\end{array}$ & 74 & 4.1496 .75 & 560.77 & & \\
\hline
\end{tabular}

Hyothesis I was tested by (2) in Table 1 . Hypothesis I. ves tested by (1) in Table I. Hyoothesis 5 was tested by the iruteraction between (1) and (2) in Trable I. 
As indicated in rable I, the rratio for Hyoothesis 4 was significknt at the .025 level of significance. Since the .025 level of significance is a greater level of precision than the .05 level, research Iypothesis 4 was accepted as tenable. That is, the adjusted mean achievement of the students with a vositive attitude toward matheratics was significantly higher than the adjusted mean achievement of the students with a negative attitude toward mathematics when holding premanxiety and pre-achievoment scores constant.

Since the other two pratios in Table I failed to be significant at the .05 level, research Hypotheses 1 and 5 were rejected. This indicates that the mean achievement of the students taught by the aid of the Spitz Student Response - System was not significantly higher than the adjusted mean achievement of the students taught by the regular lecturerecitation method and also that there was no signjficant interaction between the level of attitude and the nethod of instruction as variables affecting achievement in mathematics.

For the two-way design betwoen levels of attitude and methods of instruction, the subjects were divided into four groups, as rollows:

\begin{tabular}{|c|c|c|}
\hline & $\begin{array}{c}\text { Control } \\
\text { Grouo }\end{array}$ & $\begin{array}{l}\text { Experinental } \\
\text { Groun }\end{array}$ \\
\hline Neggtive Attitudo & I & II \\
\hline Pooltive Attituoe & ITI & IV \\
\hline
\end{tabular}


In Table II js presented the mens and adjusted means for the four grouss.

TABLE II

TABIE OF ADJUSTED NEANS AND STANDARD BRRORS FOR ACHIEVIUNEHT SCORES USING THE

PRE-ACHIEVEIVHIT: SCORES ANTD

THE PRE-SANXIETY SCORES

AS COVARIATES

\begin{tabular}{c|c|c|c|}
\hline Grous & $\begin{array}{l}\text { Group } \\
\text { Mean }\end{array}$ & $\begin{array}{c}\text { Adjusted } \\
\text { Mean }\end{array}$ & $\begin{array}{c}\text { SE Adjusted } \\
\text { Mean }\end{array}$ \\
\hline I & 51.50 & 47.94 & 4.74 \\
II & 44.70 & 49.59 & $4.71 !$ \\
III & 66.00 & 62.63 & 4.70 \\
IV & 63.50 & 65.54 & 4.72 \\
\hline
\end{tabular}

In comouting the adjusted meens, the groups were treated as separate entities using analysis of covariance with preachievernent and pre-anxiety as covariates. In this procedure, the $F$-ratio of $F=3.483$ was not signifjcant at the .05 level. This would lend support to the date presented in Table I which indicated that there was no significant interm action between level of attitude and method of instruction. An analysis of covariance with the pre-achievenent score as the covariate was rur on these sane four groups and the Huratjo was $F=2.05 \%$, This woujd tend to indscate that the 


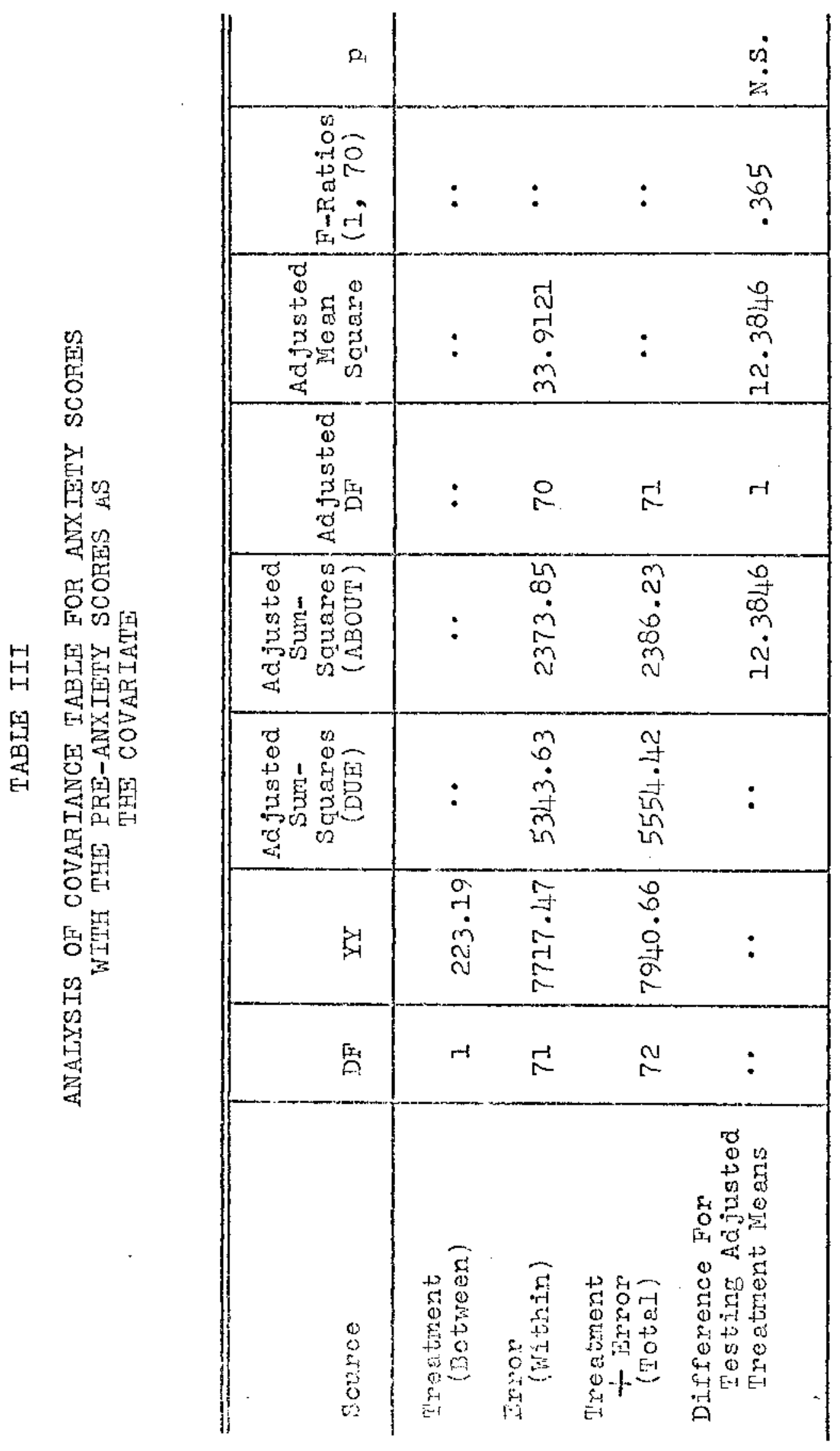


anxiety of a student oid affect his achievenent level, but the eiffect was not statisticaliy sienificant at the .05 level.

Hypothesis 2 was tested by means of analysis of covariance with the pretest anxiety score being used as the covariate. Table III indicates the results of the analysis of covariance relevant to Hyoothesis 2. As the F-ratio indicates in lable III, there was no significant difference between the adjusted mean anxiety score of the students taught with the aj.d of the Soitz Student Response System and the adjusted mean anxiety score of the students teught by the regular lecture-recitaition method.

The data presented in lable IV further substantiates the findings of $\mathrm{T}$ able III when one notices that the adjusted mean anxiety scores are essentialiy the same.

TABIE IV

TABLE OF ADJUSTED MEANS AIND STANDETD ERROLS FOR

ANX IETY SCORES USTNG THF PRE-ARXIEIY

SCORES AS THY COVARTATE

\begin{tabular}{|c|c|c|c|}
\hline Group & $\begin{array}{l}\text { Grous } \\
\text { Mean }\end{array}$ & $\begin{array}{l}\text { Adjustod } \\
\text { Mond }\end{array}$ & $\begin{array}{c}\text { SE Adjusied } \\
\text { Mear. }\end{array}$ \\
\hline Control. & 31.56 & 30.32 & .94 \\
\hline Exoerimenta? & 28.06 & 29.49 & 2. 0.1 \\
\hline
\end{tabular}




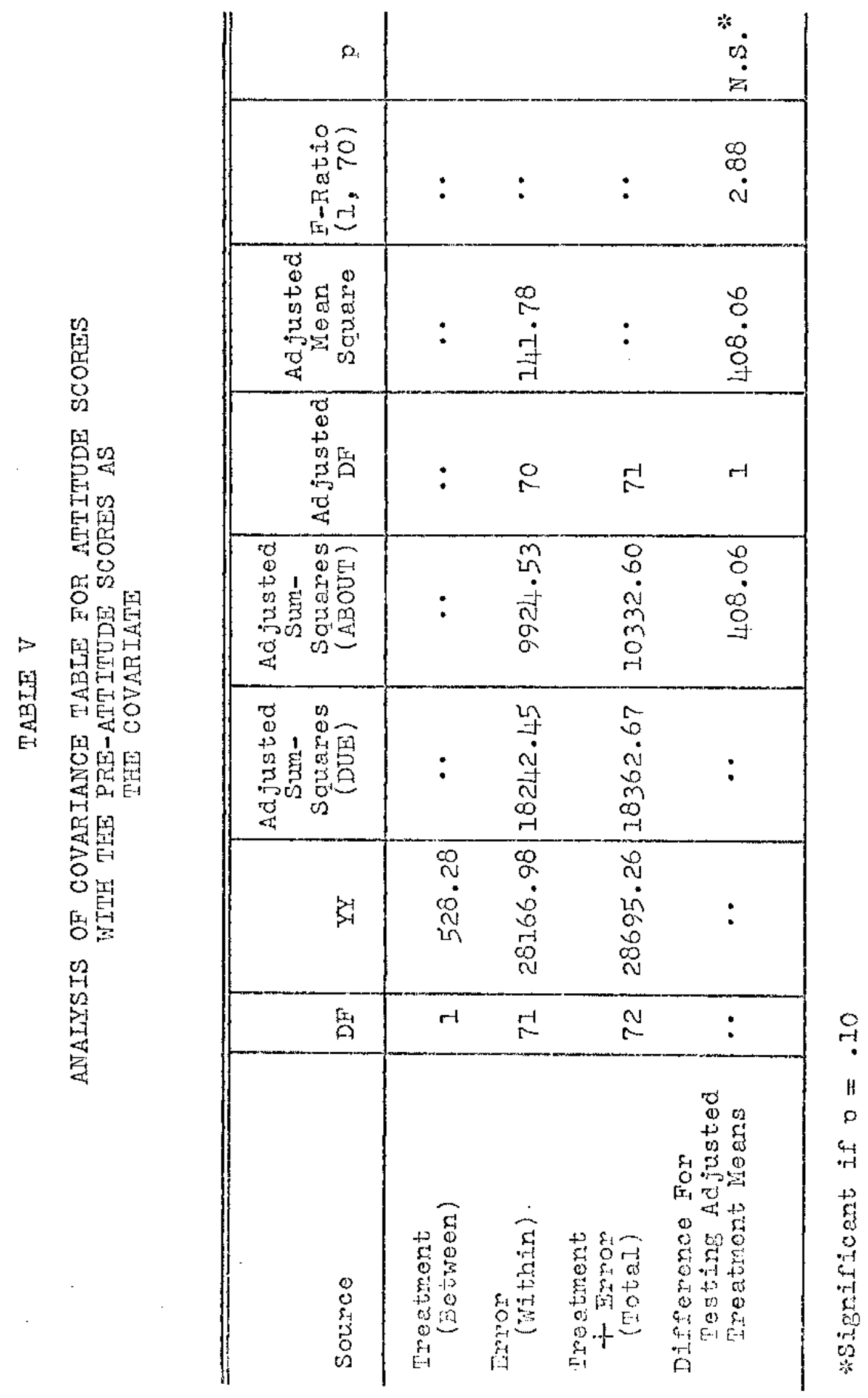


Hyoothesis 3 was tested by means of analysis of covariance with the oretest attitudic scores being used as the covariate. Table $\mathrm{V}$ indicates the results of the analysis of covariance relevant to Hyoothesis 3 .

The F-ratio, $F=2.88$, is not signiricant at the .05 level, but it is significant at the .10 level. In this study, the tenability of all the research hypotheses was tested at the .05 level. Therefore, research Hypothesis 3 must be rejected. This indicates that at the .05 Ievel, there was no significant difference between the adjusted mean positive attitude scores of the students taught with the aid of the Spitz Student Pesponse System and the adjusted mon positive attitude scores of the students taught by tine regular lecture-recitation method.

As is indicated in reble VI, there is a sizeable difference between the meanis of the two groups, but as

\section{TABTE VI}

TABIE OF ADJUSTED NEANS AND STANDARD HRRORS FOR

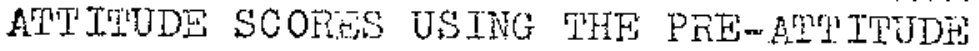
SCORES AS THE COVARIAITE

\begin{tabular}{|c|c|c|c|}
\hline Group & $\begin{array}{l}\text { Group } \\
\text { Mear }\end{array}$ & $\begin{array}{c}\text { Adjusted } \\
\text { Mean }\end{array}$ & $\begin{array}{l}\text { SFi Adjusted } \\
\text { Mear }\end{array}$ \\
\hline control & 58.87 & 59.18 & 1.91 \\
\hline Hxperimental & 64.26 & 63.92 & 2.05 \\
\hline
\end{tabular}


has already been indicated, it faijs to be signifj.cent at the .05 level.

Subjective Evaluation of the Soitz

Student Response System

During the last week of class, an evaluation form adapted from the one given by phillios (3) in his book, Evaluation in Education, was given to both the control and experimental groups. A copy of the evaluation form used in the control grouy is found in Appendix D and a copy of the from used in the experimental group is found in Apperdix. E. The basic difference in the two forms is found in question 21. This question appears only on the form used in the experimental section and it requests that the student evaluate the Spitz Student Response System. Most of the other. information gained from the evaluation is of little relevance to this study and will not be reported in this dissertation. The forms were filled out enonymously.

out of the thirty-four students in the experimental section, orly two students made somewhat negative remarks about the Spitz Student Pesponse System. These remarks were as follows:

(1) I can see no reason for its use in the course except rox the teacher's own craluation of the classes: progress.

(2) It was interesting and valuable, bui not cntire]y nocessary for the course. 
Tyoical of the remarks of the other thirty-two students are these that follow:

(I) A good educational device. Hope to see it used more in other classes.

(2) More Iike a game then a quiz - not so frightening.

(3) I think it is excellent; it tests, but is not as frightening as poo tests.

(4) It is $0 . K$. I found it valuable because the student cen tell immediatoly whether he has done a problem correctiy.

(5) I don't really know if I benerited from it, but I kind of enjoyed working with it and it helped make the class a little dirferent and more interesting. the usual.

(6) Different and interesting and more fun then

(7) The Soitz system is really great. It gives the student and teacher both a good jdea as to where he and the class are going and whet the student's weak points are. I think the system is extremely effective and would like to see it continued.

(8) The Spitz System made it possible to effectiveiy direct at tention to the areas in which students were experiencing dirficulty. It also gave students the opportunity for frequent and valuable practice on problems.

(9) Good for class participation. Could, and should, be used noro often.

(10) Heloful - you don'ts feel as if you're on the spot, especialiy if afraid of mistakes being obvious to the rest of the class.

Based uoon the anonymous renarks of the students, the Spitz Student response System ras a successul teaching aid. In the opinion of the investigator, its use heloed to keep the students straying any by day becouse of the almost dajly 
question and answer sessions. The experimental. class was ahead of the control group in its grasp of essential concepts. This was due to the additional drill and work in class, when in the question and answer session, it was indicated as being necessary. The class seemed to be enthusiastic about the system and its use and it had a very marked effect on their attitudes about rathematics. In the opinion of tine investigator, the students in the experinental section seemed to be less anxious about their mathematics class than those students in the control section.

\section{Surmany}

It has been the purpose of this chapter to oresent the data of the study. The data is sumarized in the following points:

(1) Research Hypothesis I, that the adjusted meen achievement of the students taught with the ajd of the Spitz Student Response System rould be significanty higher than the adjusted mean achievement of the students taught by the regular lecture-recitation method, was not confimed at the .05 level.

(2) Research Hyoothesis 2, that the adjusted mean anxiety score of the studerts teaght with the aid of tine Spitz Student Rosponse Syster would be signiridantiy lower than the adjusted mean enxiety scone of the 
students taught by the regular lecture-recitation methoc, was not confirmed at the .05 level.

(3) Research Hyoothesis 3, that the adjusted mean positive attitude score of the students targht with the rid of the Spitz Student Response System would be significantly higher than the adjusted mean positive attitude score of the students taught by the regular lecturemrecitation method, was not corfimed at the .05 level. However, the hyoothesis was confirmed at the .10 level of significance.

(4) Research Hypothesis 4, that the adjusted mean achievement of the students with a positive attitude toward mathematics would be signiîicantly higher than the adjusted mean achievement of the students with a negative attitude toward mathematics, was confirited at the .025 level of significance.

(5) Research Hypothesis 5, that there would be signiricant interaction between the level of attitude and the method of instruction as variables afrecting achievemcrt in mathematics, was not confimed at the .05 level.

(6) Subjective evaluation of the Spitz student Response System by the students tended to support the system as useful as a teaching device and one which improved the atidide of the students toward mathematios. 
Chaoter Five is a sumary of the experiment, ircludjng conclusions and recommendations pertinent to the findings of this study. 
1. Cooley, Wm. W., and P.R. Lohnes, Multivariate Procedures for the Behavorial Sciences, New York, Johr Wiley and Sons, Inc.s 2966.

2. Lindquist, E.F., Design and Analysis of Experiments in Psychology and Education, Boston, Houghton-ifitilin Co., 1956.

3. Phillips, Ray C., Evaluation in Education, Ohio, Charles E. Merriji Publishing Co., 1968.

4. Winer, B.J., Statistical Principles in Experimental. Design, New York, McGrew-Hill Book Co., 1962 . 
CHAPELER V V

SUMMARY, CONCIUSIONS AND

REC OMMENDATIONS

The ourbose of this chapter is to stmmarize the findings of this study, to draw conclusions based on these findings, and to make recomendations for implementation and further research.

\section{Summary}

The problem of this study was the erfect of teaching: freshmen mathematics with the Soitz Student Resoonse system uoon a student's anxiety level, attitude and achievement. The purooses of the stuay were to comore the achievement level, attitude levels and anxiety levels of students enrolled in a beginning college mathematics couree when taught by the regular lecture-recitation method and the regular lecture-recitation method augmented by the Spitz student Response System.

The subjects participating in this investigation consisted of seventy-three students enrolled in the investicator's two sections of: An Introduction to Logieal and WathematicaI Concoots, Mathematics 1308, at Southern Nethodist Jiatversity, Dallas, Texas, during the fell of 1970. M Introduction to wogical and athemation concents is a required course for a.11 non-mathmatios, non-ongineering and non-science majors. 
The exoerimental group consisted of thirity-four students and met in the suecially designed clessroon which housed the Soitz Student Resoorse Systen. The control groub consisted of thirtymine students and met in a different room earilier in the day. The investigator taught both sections.

Five hyootheses consistent with the stated purposes were fomulated, Following aro restatements of the nyootheses with a summary of the findings. The tenability of ali hyootheses of this study was tested in the null form at the .05 level of significance (two-tailed test).

Hyootheses 1,4 and 5 were tested by a $2 \times 2$ factorial analysis of covariance with the ore-anxiety and pre-achieve- ment scores as covariates. Hyootheses 2 and 3 were tested by anajysis of covariance.

Research Hyoothesis 1, that the adjusted mean achievement of the students teught with the aid o. the soitz student Response System would be significantly higher than the adjusted mean achievement of the students taught by the regular lecturemrecitation method, was not confirmed at the .05 level.

Flesearch Hyoothesis 2, that the adjusted mean anxiety score of the students taught with the aid of the sojtz Student Hesoonse Systeri would be signjficartily lower than the adjusted mean enxjety score of the students taught by the reguiar lecturemecitation method, was not confimed at the .05 level. 
Research Hypothesis 3, that the eajusted mean positive attitude score of the students taught with the aid of the Soitz Student Response Systom would be significantiy higher than the adjusted mean positive attitude score of the students taught by the regular lecture-recitation method, was not confimed at the .05 level. Howevers the hypothesis was confimed at the .10 level of significance.

Research Hypothesis 4, that the aojusted mean achieverent of the students with a positive attitude toward mathematics would be significantly higher than the adjusted mean achievement of the students with a negative attitude toward mathematics, was confirmed at the .05 level of significance.

Research Hyoothesis 5, that there would be significant interaction between the levol of attitude and the methoo of instruction as variables afrecting achievement in mathematics, was not confirmed at the .05 level.

Conclusions

Consistent with the purposes of this study and based on the enalysis of tho exporiment, certain conclusions are offered with refience to the populntion studied:

(1) Fven though differences existed in the level of' student achievernent in a beginning college mathematics course tauht; tith the aid of the Spita Student Resoonse System and we taught by the lecture-recitation method, 
the differences were not statisticaliy significant. It apoears that students learr as woll using the spitz Student Response System as by using more conventional methods. The dajly revien and drizl of the orevious day's work and the question and answer sessions in class did not significantly imorove the level of achievenent of students taught with the aid of the Soitz Student Response Systern.

(2) Even though differences existed in the level of student anxieuy in a beginning college mathenatics course taught with the aid of the Soitz student response System and one taught by the lecture-recitation method, the differences were not significant. Based uoon the subjective evaluation of the spitz system by the students, one would have to conclude that the use of the system lessened anxiety in cless by reinforeing the students' resvonses without calling attention to the indivioual student. This latter conclusion would be an important consideration in the continued use of this teaching device. Even though the use of the system does not lower onxicty, it tended to lessen the traum associated wh a matheratics class for a nonmathomatics major.

(3) Students teight by the leoturemrecitation method augmentad by the Sptiz Student Response System dorinitejy had a betion attibude toward a required

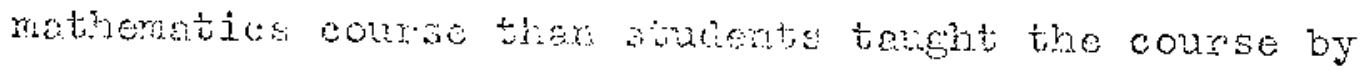


the regular lecture-recitation method. This conclusion was not only substantiated by the statistical results, but also by the daily observation of the two classes by this investigator. The use of the Soitz. Student Resoonse System tended to remove some of the fear from mathematics class and it added en elerment of interest and fun. Fihe studer.ts seerned to thoroughly enjoy the use of the systern and were especially delighted with the private reinforcemont they received on each of their responses.

(4) Students who had a positive attitude toward mathematics had a significently higher achievement level than those students who had a negative attitude toward mathematics. Even so, those students who wero taught with the aid of the soitz system and who had a positive attitude toward mathematics did not achieve significantly better than their counteroarts in the control grouo. The statistical date of this study tended to subport the idea that the efiect of attitude on achievement was independent of the method of instruction. The Soitz Syster tended to significantly raise the students' attitude level, but did not concomitantly raise their achievenent level significantiy. 
Recomnendations

Further research is recomended in several areas relative to the effectiveness of teaching boginning college mathenatics with the aid of the Soitz Student Resoonse System. Further testine in the area of levels of studert achievernent is urged. Even though no statistically significant differences existed, there were diterences. Perhaps one could design a course to make better use of the soitz. System by using the best features of programed lessons conn. bined with the best features of lecture-recitation method. With this design, problem areas in the course could be more quickly discoverod and more effectively handled in a personel. way by the teacher through this combination of orogramed and teacher-led instruction. The lessons would have the feature of smell steo leaming combined with expanded explanation by the teacher for troublesoine points.

A second area of research interest indicated by the present study involves the reasurement of change in a student's anxiety level in mathematics courses taught by a variety of technigues. According to the subjectivo evaluation of the Sojtz system by the students, the syster tended to Iessen the sjiuetional anxiety caused by being in a mathematics course. Pelraps, if an instmunt could be designed to measure situationa? anxieby as it pertains to a mathematics chass. it could denonstretio a signjicont ohenge in the student's anxiety level in e course in whoth a dovice such as 
the Spitz Syster was used. The investigator was mable to locate such an instrument and had to settle for the IPAs? test which, according to 0.11 . the authorities, is the best in existenco.

Due to the favorable subjective evaluation of the Spitz System by the students, it is the opinion of this investigator that further research should be done using the Spitz Student Response System before it is discounted as a teaching device for beginning mathematics courses. 
APPENDIX A

MATHEMATICS 1308 PIACEMENT EXAMINACION

\section{PART I}

ANSWR AEI QUESTIONS. N reoresents the set of natural numbers. Questions 3.4 answer true or false. In questions 5-14, fill in the blanks.

1. The statement $[(\phi \varepsilon \quad\{I\}) \rightarrow(\phi<\{1\})]$ is

2. For each $x \in \mathbb{N}$, there is a unique $x^{-1} \in \mathbb{N}$.

3. The operation $x \circ y=x$, for $x, y \in N$, is commutative.

4. $\{1,2,3\}$ is equivalent to $\{8,9,10\}$.

5. $[-2,3)=\{x \mid \ldots$

6. Write a statement logically equivalent to the statement, "It does not rain or we play bridge."

7. If $f(x)=2 x \quad 1, x \in N$ and $A=\{1,3,5\}$, then $f(A)=$

8. $f^{-}$and $f^{-1}$ are both functions jif and only if

9. Fivaluate: $\mid[2].] \mid$

10. Fina $x$ wich simultaneously satisfies all three conditions:

$$
x \in\{1,2,3\}, x \&\{2\},\{x, 3\} \notin\{2,3\}, x \text { is }
$$

11. If $A=\left(\begin{array}{llll}2 & 2 & 3 & 4 \\ 4 & 2 & 2 & 3\end{array}\right)$ then $A \circ A=$

12 and 1.3. Given $\mathrm{U}=\{1,2,3,4,5,6\}, \mathrm{S} C \mathrm{U}, \mathrm{T}, \mathrm{U}$. Find sets

$\mathrm{S}$ and $\mathrm{T}$ which simulaneousy satisfy all three conditions:

$\mathrm{S} \subset \mathrm{T}^{\mathrm{t}}, \mathrm{T}<\mathrm{S}^{\mathrm{t}}=\{\mathrm{J}\}, \mathrm{S} \subset \mathrm{T}, \mathrm{S} \mathrm{i}$ - T is

14. The negation of $r-\sim t$ is equivalent to 
PART II

ANSWER ALI QUEBTI IONS

1. Prove using the direct method of proot.

$$
\begin{array}{r}
\sim p \rightarrow q \\
\sim p \vee r^{p} \\
s \vee \sim r
\end{array}
$$

2. Prove using the indirect method of proof.

$$
\begin{aligned}
& \sim p \rightarrow q \\
& s \vee \sim r \\
& \sim p \vee r
\end{aligned}
$$

$q \vee s$

3. (a) What can you conclude about $p$ and about $q$, given that
$[(p \vee q) \wedge(\rightarrow q)]$ is true. Exp] in your answers.

(b) Write the negation of $[\tilde{i}(p \vee q) \rightarrow(q \rightarrow \sim p)]$ and
simplify the result.

4. (a) Prove using set theorems: $B \cup(C \cup B)^{\prime}=B \cup C^{\prime}$.

(b) Simplify using set theorems:

$$
\left[\left(C \cap D^{\prime}\right) \cup\left(C^{\prime} \cap D^{\prime}\right)\right] '=\text { ? }
$$

5. (8) Use the element inclusion method to prove: If $(\mathrm{S} \cup \mathrm{T}) \mathrm{C}$, then $\mathrm{S} C \mathrm{~T}$.

(b) Let dom $g=\{-2,-1,0,1,2\}$ and $g(x)=x^{3}$.

(I) Graph $g$. (2) Write rng $g$. (3) Find the preimage of 8 . (4) Is $g$ a function? Write out $\mathrm{g}^{-1}$.

6. Given the following:

$$
f(x)=\left\{\begin{array}{ll}
\sqrt{(-x)} \text { I } & \text { for } x \in(-3,1] \\
-2 & \text { for } x \in(1,2] \\
3-x & \text { for } x \in(2,5]
\end{array}\right]
$$

(a) Sketch the graph of $f$.

(b) $\mathrm{mg}+\mathrm{P}=$

(c) Iriage of 1 .

(d) Proimege of 7 is

(e) The tyoe of correspondence is 
7. Fill in the reasons in the following proof:

Theorem: If $x \in F$, then $-I \cdot x=\cdots x$.

Proof:

1. $x \in F$

2. $-X \varepsilon F$

3. $\quad \mathrm{X}+(-1 \cdot \mathrm{x})=(1 \cdot x)+(-1 \cdot \mathrm{x})$

4. $\quad \begin{aligned} x+(-1 \cdot x) & =(1 \cdot x)+(-1 \cdot x) \\ & =(1+(-1)) \cdot x\end{aligned}$

5. $\quad=0 \cdot x$

6. $\quad=x \cdot 0$

7. $\quad=0$

8. $\therefore x+(-1 \cdot x)=0$

9. $-1 \cdot x=-x$

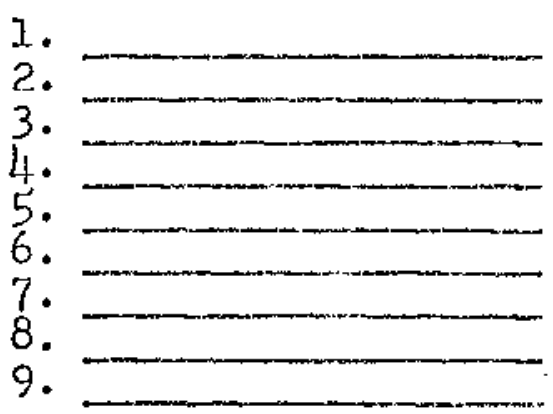

8. Do any two of the following three problems:

(a) Prove: If a $\varepsilon R$ and $a \neq 0$, then $-a \neq 0$.

(b) Prove: If $l$ is the multiplicative identity of $R-\{0\}$, then, $(-1)(-1)=1$.

(c) Prove: If $a, b, c \varepsilon F$, then $a(b-c)=a b-a c$.

9. (a) If $f=\{(1,1),(2,5),(3,9),(4,13),(5,17),(6,21)\}$, then write the formula for $r(x)$.

(b) Given $\mathrm{R}=\{(\mathrm{x}, \mathrm{y}) \mid \mathrm{x} \leq \mathrm{y}\}$ defined on $\{1,2,3\}$. (1) Is dom $R=\operatorname{mg} R^{T}$ (2) Is $R$ refiexive? (3) Is $R$ symmetric? (4) Is $R$ transitive? (5) Name type of correspondence, and deternine whether dom $\mathrm{R}$ is equivalent to the ring $R$.

10. Given: $U=\{1,2,3,4,5,6\}, A=\{2,3,4,6\}, B=\{4,4,6\}$,

(a) Write out the following: (1) $C-(A \cup B)$. (2) $(A \cup B)$ '.

- (3) $U \cap C^{\prime} \cdot$ (4) $(B \cap C)-A \cdot(5)(A-B)-C$. (6) $\mathrm{D} \times \mathrm{B}$.

(b) If $R=(C-D) x_{-1} D$, then (1) Write out $R$; (2) dom $R=$ ? (3) Is $R^{-I}$ a function? (4) Is $R$ refiexive on $\mathrm{C} \cup \mathrm{D}$ ? 


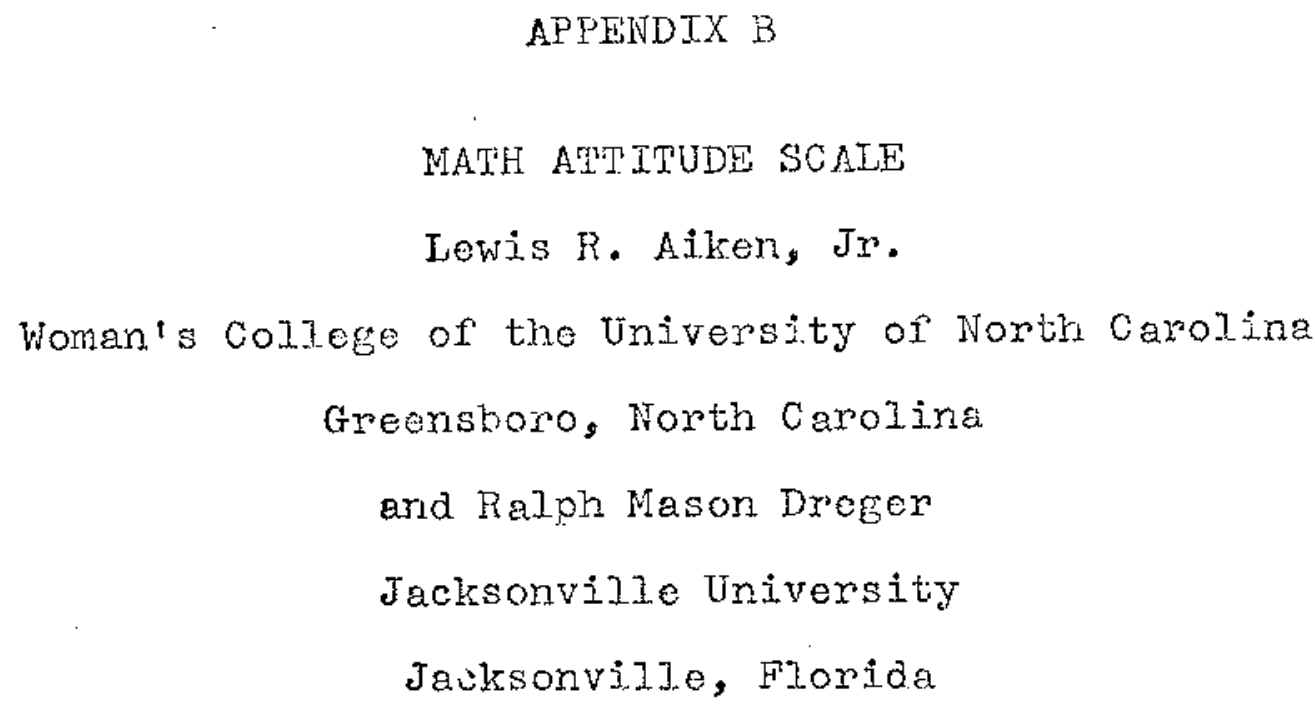

NAME

$O P I N I O N N A I R E$

DIRECTIONS: Please write your neme in the upper right hand corner. Each of the statements or this opirionnaire expresses a feeling which a particular person has toward mathematics. You are to express, on a five-point scale, the extent of agreament between the feeling expressed in each statement and your ow personal feeling. The five points are: Strongly disagree (SD), Disagrec (D), Undecided (U), Agree (A), Strongly agree (SA). You are to encircle the letter(s) which best indicates how closely you agree or disagree with the feeling expressed in each statement AS IT CONCERNS YOU.

1. I do not like mathematics. I ain always under a terrible strain in a math class.

SD $\quad D \quad U \quad A \quad S A$

2. I do not like mathomatics, and it scares me to have to take it.

SD D U A SA

3. Mathomatics jos very interesting to me. I enjoy math courses.

SD D U A SA

4. Wathemation is focinating and fux.

SD D U A SA 
5. Mathematics makes mo feel secure, and at the sarie time it is

stimulating.

SD $\quad$ D $\quad$ U A $\quad$ A $S A$

6. I do not ike mathomatics. My mind goes blark, and $I$ am unable to think clearly when working math.

SD D U A SA

7. I feel a sense of insecurity when

attemoting natheratics.

$S D$ D U A SA

8. Mathematics makes me fee]. unconfortable, restless, irritable, and impatient.

SD D U A SA

9. The feeling that I have toward mathenatics is a good feeling.

SD D U A SA

10. Mathornatics makes me feel as though I'm lost in a jungle of numbers and can't f'ind my way out.

SD D U A BA

11. Mathematics is something which I enjoy a great deal.

SD D U A SA

12. When I hear the word math, I have a feeling of dislike.

$S D \quad D \quad U \quad A \quad S A$

13. I approech math with a feeling of hesitation - hesitation resulting from a fear of not being able to do math.

14. I really like mathematics.

SD D U A SA

$S D$ D U A SA

15. Mathematics is a course in school which I have aiways liked and enjoyed studying.

$S D \quad D \quad U \quad A \quad S A$

16. I don't like nathematicis. It makes me nervous to ever think

about heving to do a nath problen.

SD D U A SA

17. I have never liked math, and it is my most droaded sub ject.

$S D$ D U A SA

18. I love mathenatics. I am happier in a meth elass then in any other c]ess.

$S D$ D U A $B$ 
19. I feel at oase in mathenatios, and $t$ like it vory much.

SD D U A SA

20. I feel a definite positive reaction to mathemstics; it's enjoyable.

SD D U A SA 


\section{SELF ANALYSIS FoRM}

NAME. First

Middle

Last

TODAY'S DATE

SEX

(Write $\mathrm{M}$ or $\mathrm{F}$ )

AGE

(Nearest Year)

OTHER FACTS.

(Address, Occupation, etc, as instructed)

Inside this booklet you will find forty questions, dealing with difficulties that most people experience at one time or another. It will help a lot in self-understanding if you check Yes, No, etc., to each, frankly and truthfully, to describe any problems you may have.

Start with the two simple examples just below, for practice. As you see, each inquiry is actually put in the form of a sentence. By putting a cross, $\mathrm{X}$, in one of the three boxes on the right you show how it applies to you. Make your marks now.

\section{I enjoy walking.}

A middle box is provided for when you cannot definitely say Yes or No. But use it as little as possible.

\section{I would rather spend an evening:}

(A) talking to people, (B) at a movie.

About half the items inside end in $A$ and $B$ choices like this. $B$ is always on the right. Remember, use the "In between" or "Uncertain" box only if you cannot possibly decide on $\mathrm{A}$ or $\mathrm{B}$.

Now:

1. Make sure you have put your name, and whatever else the examiner asks, in the place at the top of this page.

2. Never pass over an item but give some answer to every single one. Your answers will be entirely confidential.

3. Do not spend time pondering. Answer each immediately, the way you want to at this moment (not last week, or usually). You may have answered questions like this before; but answer them as you feel now.

Most people finish in five minutes; some, in ten. Hand in this form as soon as you are through with it, unless told to do otherwise. As soon as the examiner signals or tells you to, turn the page and begin.

\section{STOP HERE-WAIT FOR SIGNAL}

(9) 1957, 1963, by R. B. Cattell. All rights reserved. Printed in U. S. A. Published by the Institute for Personality and Ability Testing, 1602-04 Coronodo Drive, Chompolign, Illinois. 
1. I find that my interests, in people and amusements, tend to change fairly rapidly.

2. If people think poorly of me I can still go on quite serenely in my own mind

3. I like to wait till I am sure that what I am saying is correct, before I put forward an argument.

4. I am inclined to let my actions get swayed by feelings of jealousy.

5. If I had my life to live over again I would:

(A) plan very differently, (B) want it the same.

6. I admire my parents in all important matters.

7. I find it hard to "take 'no' for an answer", even when I know what I ask is impossible.

8. I doubt the honesty of people who are more friendly than I would naturally expect them to be.

9. In demanding and enforcing obedience my parents (or guardians) were: (A) always very reasonable, (B) often unreasonable.

10. I need my friends more than they seem to need me

11. I feel sure that I could "pull myself together" to deal with an emergency

12. As a child I was afraid of the dark

13. People sometimes tell me that I show my excitement in voice and manner too obviously.

14. If people take advantage of my friendliness $I$ :

(A) soon forget and forgive, (B) resent it and hold it against them.

15. I find myself upset rather than helped by the kind of personal criticism that many people make.

16. Often I get angry with people too quickly

17. I feel restless as if I want something but do not know what

18. I sometimes doubt whether people I am talking to are really interested in what I am saying..

19. I have always been free from any vague feelings of ill-health, such as obscure pains, digestive upsets, awareness of heart action, etc.

20. In discussion with some people, I get so annoyed that I can hardly trust myself to speak. (n) $\square \stackrel{\text { True between Palne }}{\square}$
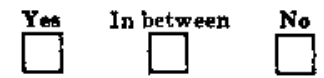

timet

Seldom

Never

A In between

$\stackrel{8}{\square}$

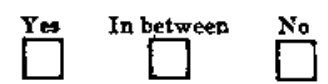

True In between

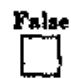

True

In between

Fane

$\square^{\text {In between }}$

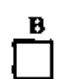

Rarely Sometton

often

Always

Often Seldom

often

Sometimes

Never

Yes Uncertain

No

In between

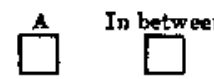

B

Often Oecestionelly Never
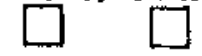

Tru

In between

Falne

very
rarely

Sometimea

often

Tro

In between

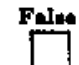

T

$\square^{\text {Uncertatin }}$ 
21. Through getting tense I use up more energy than most people in getting things done.

22. I make a point of not being absent-minded or forgetful of details

23. However difficult and unpleasant the obstacles, I always stick to my original intentions

24. I tend to get over-excited and "rattled" in upsetting situations

25. I occasionally have vivid dreams that disturb my sleep

In between

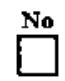

$\square$

In between

Yen In between

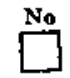

27. I sometimes feel compelled to count things for no particular purpose...

28. Most people are a little queer mentally, though they do not like to admit it

29. If I make an awkward social mistake I can soon forget it

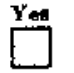

In between

In between

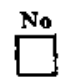

30. I feel grouchy and just do not want to see people:

(A) occasionally, (B) rather often..

'31. I am brought almost to tears by having things go wrong

32. In the midst of social groups I am nevertheless sometimes overcome by feelings of loneliness and worthlessness

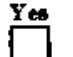

33. I wake in the night and, through worry, have some difficulty in sleeping again

34. My spirits generally stay high no matter how many troubles I meet.....

.35. I sometimes get feelings of guilt or remorse over quite small matters...

36. My nerves get on edge so that certain sounds, e.g., a screechy hinge, are unbearable and give me the shivers.

37. If something badly upsets me I generally calm down again quite quickly

38. I tend to tremble or perspire when I think of a difficult task ahead........

39. I usually fall asleep quickly, in a few minutes, when I go to bed
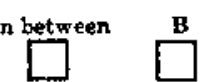


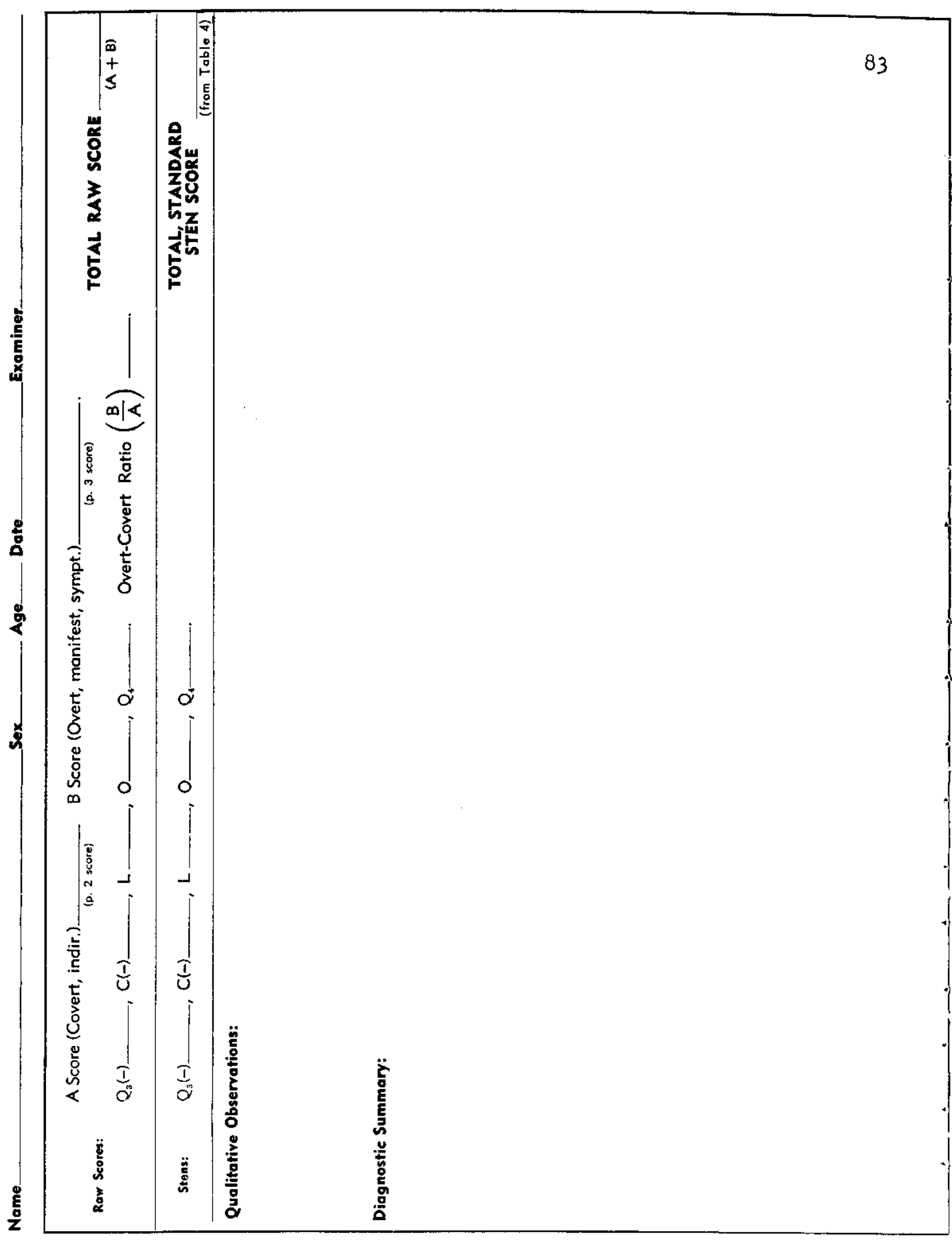


APPENDIX D

STUDENT EVALUATION SCALE

Directions: Do not sign your ngme to the questionaju. Indicate your evaluetion of the teaching and learning situation in this class by placing a circle around the appropriate numbor for each item, using the following system:

$\begin{array}{lllll}5 & 4 & 3 & 2 & 1\end{array}$

Outstanding Above Average Average Below Average Poor

0

If' undecided or no opportunity to observe

1. Ability to create interest in the subject matter and to stimulate thinking.......... 43210

2. Value of lectures and class activities to your understanding................. 4 4 3210

3. Value of cutside assigments to understanding of the course............ 43210

1. Teacher's knowiedge of his subject

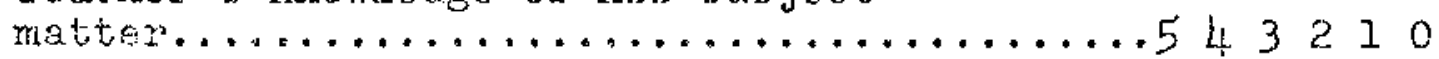

5. Demonstimation of knomiedge through

teachirg.......................... 43210

6. Orfertigetion and prosontation of course

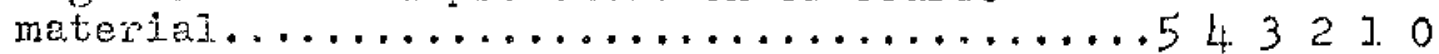

7. Ability to sinplify and explain complex

- subject mative........................ 43210

8. Accessibjitity end wijingness of teacher to heio students inrividually......54 43210

9. Imoretality ard iniruos in dorlings

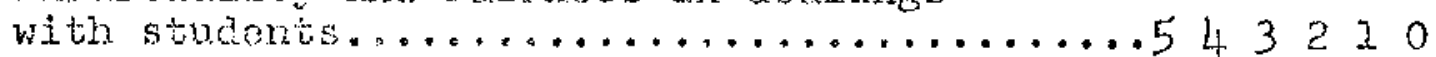

10. Well-belanced coverage of coirse meterial in tests....................... 32 2. 10

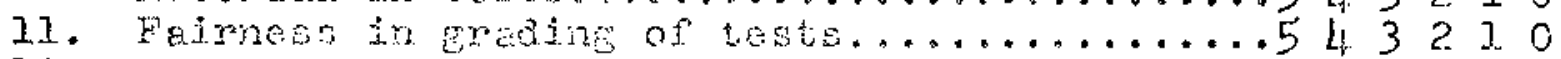

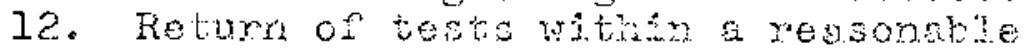
length of time...................... 43210

13. Wffective ves of tarthools eiralor supplementery rilatorial to ormanoe

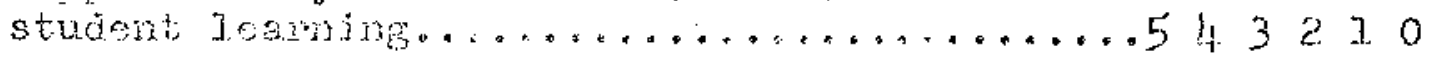


14. Generaj appearance of teacher (neat, clean, well-groomed).................543210

15. Willingness to allow students to

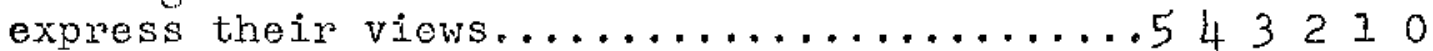

16. Considering everything, evaluate the teacher's general teaching effectiveness....54321 0

17. Considering everything, compare the teacher's effectiveness with that of other courses of this type............54321 0

18. What suggestions would you of fer for the improvement of this course?

19. What is the general "climate" of the classroom (eg. relaxed, tense, warn, co d, friendly, hostile, etc.)?

20. Draw a circle around the $\mathrm{X}$ that most nearly expresses your feeling about the course.

Very Satisfied
Quite Satisfied

$\mathrm{X}$

X

$X$

X

Somewhat Satisfied
Very

Disertisfied

X 
APPENDLX E

\section{STUDFHT EVAIUATION SCAES}

Directions: Do not sign your name to the questionnaire. Indicate your evaluation of the teschirg and leaming situation in this class by placing a circle around the appropriate number for each item, using tho following system:

$\begin{array}{lllll}5 & 4 & 3 & 2 & 1 .\end{array}$

Outstarding Above Average Average Below Average Poor

C

If undecided or no opportunity to observe

1. Abijity to create interest in the subject matter and to stimulate thinking........54321 0

2. Value of lectures and class activities

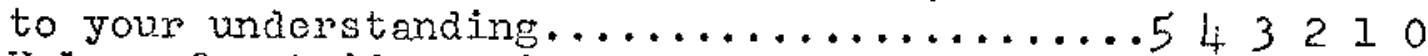

3. Value of outside assjgnments to understanding of the course..............543210

4. Meacher's knowledge of his subject

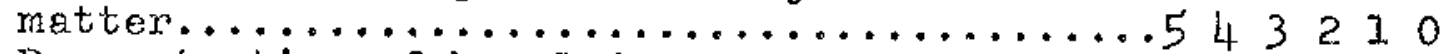

5. Demongtration of knowledge through

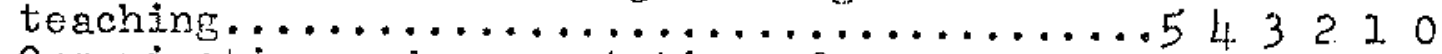

6. Organization and presentation of

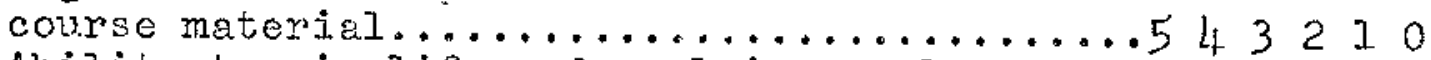

7. Ability to simolify and explain complex

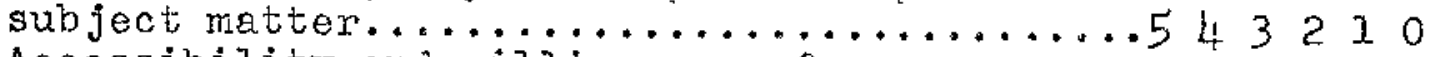

8. Accessibility and wiljingness of teacher to help students individually.....5 4 3210

9. Impartiality and fairness in dealings with studentis.........................

10. Well-balanced coverage of course ratorial

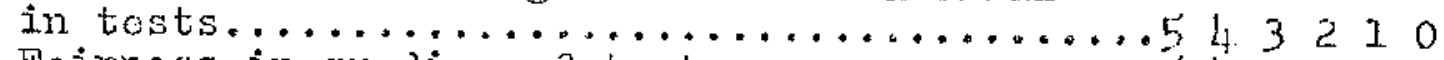

11. Fairness in grading of tests..........5 i 3210

12. Return of tests within a reasonable length of time...................5 4 . 310

13. Effective use of taxtbooks andor supplementary ratorit to enizence student learning...................543210 
14. General avoearance of teacher (neat,

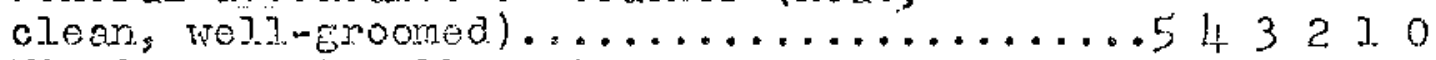

15. Willingness to allow studonts to express the ir views..................... 4210

16. Considering everything, eveluate the teacher's generel teaching effectiveness....5 43210

17. Considering everything, corpare the teacher's effectiveness with that of other courses of this type.............54 3210

18. What suggestions would you offer for the improvement of this course?

19. What is the general "climate" of the classroom (eg. relaxed, tense, warm, cold, friendly, hostile, etc.)?

20. Draw a circle around the $\bar{X}$ that most nearly expresses your feeling about the course

\begin{tabular}{|c|c|c|c|c|}
\hline $\begin{array}{l}\text { Very } \\
\text { Satisfied }\end{array}$ & $\begin{array}{c}\text { Quite } \\
\text { Satisfied }\end{array}$ & $\mathrm{Sc}-\mathrm{So}$ & $\begin{array}{l}\text { Somewhat } \\
\text { Satisfied }\end{array}$ & $\begin{array}{c}\text { Very } \\
\text { Disentisfied }\end{array}$ \\
\hline $\mathrm{X}$ & $X$ & $x$ & $\mathrm{X}$ & $X$ \\
\hline
\end{tabular}

21. Evaluate the Spitz Student Fiesponse System and its use in this course. 


\section{BIBLIOGRAPHY}

\section{Books}

Biggs, John B., "The Psychopathology of Arithmetic," Ney Approaches to Tesching Mathematics, Editor F.W. Land, New York, St. Martin's Press, 1965.

Buros, Oscar K., Editor, The Sixth Mentel Measurements Yearbook, Highland Park, Ilinois, The Gryphon Press, 1965 .

Campbe1I, D.T. and J.C. Stanley, Experinental and QuasiExperimental Designs for Research, Chicago, Rano MicNaliy \& Co., 1966 .

Cooley, Wm. W. and P.R. Isohnes, Multivariate Procedures for the Behsvonial Sciences, Wew York, John Wiley \& Sons, Inc. 1966 .

Dabrowski, K., Positive Disintegration, Boston, Little, Brown \& Co., 1964 .

Edwards, Allen L., Techniques of Attjtude Scale Construction, New York, Apoleton-Century-Crofts, Inc., 1957.

Freeman, M.J., "The Development of a Test for the Measurement of Anxiety: A Study of i.ts Reliability and Validity," Psychology Morograchs, Editor H.S. Conrad, New York, American Psychology Association, 1953.

Klein, E., "Psychoanalytic Aspects of Scholastic Problems," Eiditors A. Freud and H. Hartran, Psychoanalytic study of the Child, III-IV, New Yoxk, Intemational Universities Press, 3949.

Levy, D.M., Maternal Overorotection, New York, Columbia University Eress, $194 \%$.

Lindquist, E.P., Design and Anglysis of Expexinents in

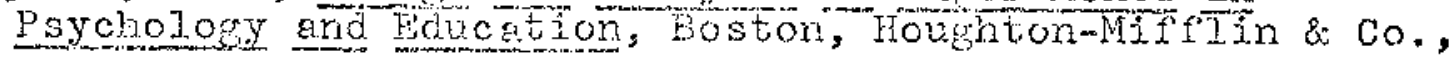

McKeachie, W.J., Motivation, Teaching Methods and College Learrings," Faitor li, R, Jones, Nebraska Symoosium on Motivation, Irincoln, University of Nebraske Freas, I961. 
Miller, N.E., and J. Dollard, Socta? Ieaming and Imitation, New Haven, Yale Univorsity jress, 19L1.

Murray, Jas. A.H., et.al., The Oxford Ensizh Dictionary, London, University of oxford Press, 1933.

Phijlios, Ray C., Evaluation in Fducation, onio, Charles E. Merrili Pubjishing Co., 1968.

Plank, E.N. and R. Plank, "Emotional Componentis in Arithretical Legrning as Seen Through Autobjographies," Editors A. Freud and E. Kris, Psychoaralytic Stuoy of the Child, IX, New York, International Universities Press, 1952.

Rethlingshafer, Dorthy, Motivation as Related to Personality, New Youk, McGraw-HiII, 1963.

Roscoe, J.T., Fundamontal Research Statistics, Dallas, Holt, Rirehart and Winston, 1969.

Ruebush, B.K., "Anxjety," Chjld Psychology, Sixty-Second Yearbook of the National Society for the Study of Education, Part I, Chicago, Jniversity of Chicago Press, 1.963.

Sarason, S.B., et.al., Anxiety in Elerientary School Children, New York, John Wiley and sons, Inc., 1960 .

Sax, G., Empirical Foundations of Educational Research, New Jerscy, Pronticentali, I968.

Scheier, I.H. and R.B. Cattell, Handbook for the IPAT Anxiety. Scaje ouestionnaje, Iljinois, Institute for personeity and Ability iesting, 1967.

Schonell, F.r., Diagnosis of Individual Differences in Arithmetic, Edinburgh, OJjer arid Boyd, 1937.

Shar, M.E., and J.M. Wright, Scales for the Measurenent of

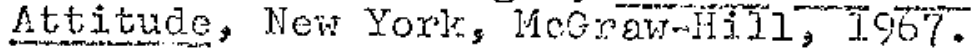

Winer, E.J., Statistical Princioles In Fxperimental Design, New York, McGrom

Woodworth, R.S., Dywarice of Behavior, New York, Henry Holt and compsy, 1950. 
Articies

Aiken, I.R., Jr. and R.M. Droger, "The Effects of Attitudes or Perínance in Matheratics," Joumal of Educetjonel Psychology, 111 (1961), 19-24

Aiken, L.R., Jr., Mathemaohobia and lithemaphilia: An Analysj.s of Personel and social Factors Affecting Performance in Malronatics," Dissertietion Abstracts, $1960,0.1992$.

, "Affective Factors in Matheratics Leaming: Comments on a Paper by Neale and a Plac for Pesearch," Journat For Research in lethematics jucation, I (1970), $251-255$.

_......... "Attitudes Toward Mathematics," Review of Educationed Researchs XI (1970), 55l-596.

Aloert, ‥ and R. N. Haber, "Anxiety in Acaderic Achievernent Situations," Journel of Abnomal and Sociolosicel. Psycholory, IXI $(3.960), 207-215$.

Anttonen, R.G., "A Longitudinal Study in Mathematics Attitude," Journal of Educetional Research, IXII. (1969), 467-471.

Bassham, Harrell, "ieacher Understanding and Fuoil Efícioncy in liathematics - A Study of Pelationshios", The Arithmetjc 1eacher, JX (November, 1962), $383 * 387$.

Bendiz, $A$.W., "The Development of a Short Form of the Manifest Anxiety Scale," Journa of Consulting Psychologists,
$\mathrm{XX}(1.956), 384$.

Dreger, R.M. and I.R. Aiken, Jr., "The Identification of Number Anriety in a College Pooulation," Journal of Educational Research, XLVITJ $(3957), 344-351$.

Dutton, U.H., "Attitudes of Junjor ujgh School. Pupils Toward Arithmetic," School Review IXIII (Januery, 1956), 18-22.

- "Weasuring Attitude Noward Arithmetic," Elenentary Scbool Journel, I954-55, 24-32.

Fatat, CFairo E., "A Sudy of the Rolationship Between Attitude and Achievement in Soloctod Elementary School Subjects," Dissertation Abstracts, XxIII (Hebruary, 1963), 2752-2753.

Fedon, Petcr, "The Role of Attitude jn Leaming Aritmetic," The Arithrette iederer, V (December, 1958), 304-310. 
Haskel1, Simon, "Sorne Observations on the Effects of Class Size Upon Pupil Achievernent in Geometrical. Drawing," Journal of Educational Roseareh, JiII (September, 1964), $27-30$.

Hess, Echnard H., "Attitude and Pupil Size", Scientific Amexican, CCXII (Apri1, 1965), 46-54.

Milliken, R.I., "Mathematical-Verbal Ability Differentials of Situational Anxiety as Measured by Blood Pressure Change," Journal of Experimental Education, XXXII, (September, 1964), 309-311.

and Bernard Spolka, "Mathematicaj-morbal Ability Differentials and Somatic Expressions of Situational Anxiety," Journal. of Exoeririental Education, XXXI (September, 1962$), 3-26$.

Morgan, Jas. H., "The Relationship Between Ievels of Anxiety and Mathematics Achievement in Programined and TeacheiDirected Instruction, "Dissertation Abstracts, XXV $(1965), 3760$.

Neidt, C.0., and D.E. Hedlund, "The Relationship Between Changes in Attitude Toward a Course and Final Achievement," Journal of Educatjonal. Research, LXI (1967),

Phjllips, B.N., "Sex, Social Class, and Anxiety as Sources of Variation in School Achievement, "Jourmal of Educational Psycholory, LIII, 316-322.

Pofferberger, Thomas and Donald Norton, "Factors in the Formation of Attitudes "Poward Mathematics, Journal of Educational Research, IJII (January, 1959), 171-176.

"Factors Detemining At itudes Ioward Arithmetic and Mathomatics," The Arithmetic Teacher, III (ApriI, 1.956), 113-1.16.

Rethilingshafer, Dorthy, Motivation as Related to Personality, Now York, McGrawmili, 1963 .

Riggs, Cassidy Leroy, "The Rolationsinip or Anxiety and Anxiety Adaptation to Aptitude, SelfmConcept, and Schoiastic Achievement," Dissortation Abstracts, XXII (1961), 3927.

Sarason, Irwin G., "Empirical Findings and Theoretical Problems in the Use of Anxiety Scales," Psychological BuIIetin, J.VII (1960), 403-4.15. 
Sarason, Irwin $G$ " "Mrtermelationships Amone Individual

Difiering Verjebles; Behavior in Psybotkerapy, and Veroal Conditioning;" Trumel of Abmogmal and Sociological Psychology LVI (1950), 339-34h.

Sarason, S.B., G. Mandlex, and P.G. Oxaighill, "The Effect of Djfferential. Instruetions on Anxiety and Leaming," Journal of Abnoringl and Sociological Psychology, XIVII $(1952), 561-565$.

, K. Davidsons et.21., "Classroom Observation of High and Ion Arxious Children," Child Development, XXIx (1958), 287-206.

"Soity Student System for Large Group Instruction" in Advertisement by Spitz Laboratorjes, Inc., Chadds fora, Pennsylvania, A Division of McGraw-Hill, Inc.

Taylor, Janet A., "The Relationship of Anxiety to the Conditional Eyelid Response," Jourmal of Exoerimentaj Psychology, XJI (1951), 81-92.

"A Personality Scale of Hanifest Anxiety," Jouma of Abnorial and Socjological Peychology, XIVTIE $(1953), 285-290$.

, "Drive Theory and Manif'est Anxiety:" Psychology Bulletin, LII (1956), 303-320.

Pulok, M.K., "Emotional. Blocks in Mathomatics," Mathematics Teacher, $V(1957), 572-6$.

Weish, Geo. S., "An Anxiety Index and an Internalization Fiatio for the MPI," Jouras of Consulting Psychologists, $X V I(1.962), 65 \cdots 72$.

White, W. F. and Robert I. Aaron, "Teacher's Motivational Cues and Anxiety in Relation to Achievement Levels in Secondary School Mathematics," Joumal of Educationel Research, IXI (1967), 6m9.

Zweibelson, Irving and F.J. Lodeto, "Relationship of Fupjt Anxiety and Attituce to Arithmetic Readiress and Achievement," Psychology in the Schools, TI (1965), $140-2$. 